\title{
A long-term study on zooplankton in two contrasting cascade reservoirs (Iguaçu River, Brazil): Effects of inter-annual, seasonal, and environmental factors
}

\author{
Pablo H.S. Picapedra \\ , Cleomar Fernandes ${ }^{2}$, Juliana Taborda \\ Gilmar Baumgartner \\ 1$$
3
$$ \\ Corresponding Author: Pablo H.S. Picapedra \\ Email address: pablo_picapedra@hotmail.com
} Paulo V. Sanches ${ }^{1,2}$

2

Background. In reservoirs, zooplankton strongly interact with the physical and chemical characteristics of water, and this interaction is mainly influenced by climate variation and the different methods used to manage the dam water level. Therefore, the aim of this study was to evaluate how the distinct operating modes of two cascade reservoirs affected the richness, abundance, and composition of zooplankton, both spatially (intra and interreservoirs) and temporally (annual and seasonal). In this study, the upstream reservoir (Salto Santiago) operates using the storage method, with a water retention time (WRT) of 51 days, whereas the downstream reservoir (Salto Osório) operates using the run-of-river method, with a WRT of 15 days. Methods. Zooplankton samples were collected for 16 consecutive years from the two reservoirs located on the Iguaçu River, Brazil. A total of 720 samples were collected. Four-way ANOVAs were used to determine the differences in richness and abundance of the zooplankton among years, periods, reservoirs, and environments. Multidimensional non-metric scaling (NMDS) and an analysis of similarities (ANOSIM) were used to describe similarity patterns in species composition. Finally, a canonical correspondence analysis (CCA) was used to select the environmental predictors that best explained the variation in zooplankton abundance data. Results. We identified a total of 115 taxa in this study, and rotifers were the richest group. In contrast, the copepods were the most abundant. The four-way ANOVA results showed significant differences in the species richness and abundance of the zooplankton among years, periods, reservoirs, and environments. The NMDS ordination and ANOSIM test indicated that the largest differences in zooplankton species composition were annual and seasonal differences. Finally, the CCA showed that these differences were mainly associated with changes in water transparency, temperature, and the chlorophyll a, phosphorus, and total 
dissolved solids concentrations. Discussion. Inter-annual changes in zooplankton species composition showed that over time, large filters-feeders (e.g., large daphinids and calanoid copepods) were replaced by small cladocerans (e.g., bosminids) and generalist rotifers. The highest species richness was associated with the fluvial environment, whereas the highest abundance was associated with the transitional and lacustrine reservoir environments. Variations in water temperature, nutrients, and food availability explained the annual and seasonal changes in community structure, whereas variations in the water flow characteristics of the environments explained the longitudinal changes in the richness and abundance of zooplankton in reservoirs. The differences in zooplankton structure between the two reservoirs can be explained by the functional differences between the two systems, such as their WRTs and morphometrics. 
1 A long-term study on zooplankton in two contrasting

2 cascade reservoirs (Iguaçu River, Brazil): Effects of

3 inter-annual, seasonal, and environmental factors

\author{
Pablo H.S. Picapedra ${ }^{1}$, Cleomar Fernandes ${ }^{2}$, Juliana Taborda ${ }^{1,2}$, Gilmar Baumgartner ${ }^{1,2}$ and
} Paulo V. Sanches ${ }^{1,2,3}$

${ }^{1}$ Programa de Pós-Graduação em Recursos Pesqueiros e Engenharia de Pesca, Universidade Estadual do Oeste do Paraná, Toledo, Paraná, Brazil

${ }^{2}$ Grupo de Pesquisas em Recursos Pesqueiros e Limnologia/Instituto Neotropical de Pesquisas Ambientais, Toledo, Paraná, Brazil

${ }^{3}$ Programa de Pós-Graduação em Ciências Ambientais, Universidade Estadual do Oeste do Paraná, Toledo, Paraná, Brazil

Corresponding Author:

Pablo Picapedra ${ }^{1}$

Rua da Faculdade, Toledo, Paraná, 85903000, Brazil

Email address: pablo_picapedra@hotmail.com

\title{
Abstract
}

Background. In reservoirs, zooplankton strongly interact with the physical and chemical characteristics of water, and this interaction is mainly influenced by climate variation and the different methods used to manage the dam water level. Therefore, the aim of this study was to evaluate how the distinct operating modes of two cascade reservoirs affected the richness, abundance, and composition of zooplankton, both spatially (intra and inter-reservoirs) and temporally (annual and seasonal). In this study, the upstream reservoir (Salto Santiago) operates using the storage method, with a water retention time (WRT) of 51 days, whereas the downstream reservoir (Salto Osório) operates using the run-of-river method, with a WRT of 15 days.

Methods. Zooplankton samples were collected for 16 consecutive years from the two reservoirs located on the Iguaçu River, Brazil. A total of 720 samples were collected. Four-way ANOVAs were used to determine the differences in richness and abundance of the zooplankton among years, periods, reservoirs, and environments. Multidimensional non-metric scaling (NMDS) and an analysis of similarities (ANOSIM) were used to describe similarity patterns in species composition. Finally, a canonical correspondence analysis (CCA) was used to select the environmental predictors that best explained the variation in zooplankton abundance data.

Results. We identified a total of 115 taxa in this study, and rotifers were the richest group. In contrast, the copepods were the most abundant. The four-way ANOVA results showed significant differences in the species richness and abundance of the zooplankton among years, 
40 periods, reservoirs, and environments. The NMDS ordination and ANOSIM test indicated that

41 the largest differences in zooplankton species composition were annual and seasonal differences.

42 Finally, the CCA showed that these differences were mainly associated with changes in water

43 transparency, temperature, and the chlorophyll $a$, phosphorus, and total dissolved solids

44 concentrations.

45 Discussion. Inter-annual changes in zooplankton species composition showed that over time,

46 large filters-feeders (e.g., large daphinids and calanoid copepods) were replaced by small

47 cladocerans (e.g., bosminids) and generalist rotifers. The highest species richness was associated

48 with the fluvial environment, whereas the highest abundance was associated with the transitional

49 and lacustrine reservoir environments. Variations in water temperature, nutrients, and food

50

51 availability explained the annual and seasonal changes in community structure, whereas variations in the water flow characteristics of the environments explained the longitudinal changes in the richness and abundance of zooplankton in reservoirs. The differences in zooplankton structure between the two reservoirs can be explained by the functional differences between the two systems, such as their WRTs and morphometrics.

\section{Introduction}

57
Rising air and water temperatures and changes in hydrological conditions caused by alterations in rainfall seasonality or availability are among the major global concerns of our day (Nobre et al., 2016; Rocha et al., 2019). In some countries, these concerns are even more relevant owing to their large quantity and diversity of aquatic ecosystems. Currently, one of the biggest challenges has been to predict the consequences of climate change on reservoir systems (Paerl \& Paul, 2012). Reservoirs are inseparable components of most rivers in South America (Agostinho et al., 2016). These engineering works have become increasingly prolific in major river basins, mainly owing to the natural conditions of their predominantly free-flowing rivers, which mean that they have high hydroelectrical potential (Cella-Ribeiro et al., 2017). However, a dam significantly alters the riverine ecosystem (Silva et al., 2014; Oliveira et al., 2018) because the reservoir blocks the free flow of the river and creates a semi-lentic or lentic habitat (Baxter, 1977). Important factors, such as the quantity and quality of the water, habitats, nutrient and sediment transport, and water retention time (WRT) can dramatically change (Baumgartner, Baumgartner \& Gomes, 2017; Loken et al., 2018). Thus, either directly or indirectly, artificial variations in water level can affect all aquatic organisms, from primary producers (phytoplankton) to consumers (zooplankton, macroinvertebrates, and fish) (Baumgartner et al., 2019).

Therefore, the environmental heterogeneity of physical and chemical characteristics and the type of dam operation are the main drivers of biotic structure (Vinebrooke et al., 2004). The operation of dams basically follows two patterns: storage and run-of-river (Nogueira, PerbicheNeves \& Naliato, 2012). Storage reservoirs have lentic characteristics and a long WRT, which means that changes occur in the variability of the natural flow regime, as well as associated characteristics, such as the magnitude, frequency, duration, and time and rate of this variability (Biggs, Nikora \& Snelder, 2005). However, run-of-river reservoirs have semi-lotic characteristics 
80

81

82

83

84

85

86

87

88

89

90

91

92

93

94

95

96

97

98

99

100

101

102

103

104

105

106

107

108

109

110

111

112

113

114

115

116

117

118

119

and may accumulate a limited amount or no water and have a short WRT (Perbiche-Neves \& Nogueira, 2010; Tang \& Cao, 2018). These differences in hydrological conditions and limnological characteristics may lead to different zooplankton communities throughout the environments of these two types of reservoirs. In addition, seasonal influences may be more or less pronounced according to the operating mode of the reservoir (Sartori et al., 2009; McManamay et al., 2016). Fast responses to climate change are expected in systems where lotic conditions predominate, unlike reservoirs operated as lentic environments (Perbiche-Neves \& Nogueira, 2013).

Although the importance of longitudinal spatial compartments on zooplankton dynamics in reservoirs is understood (Marzolf, 1990; Nogueira, 2001), few studies have clarified the mechanisms responsible for zooplankton community variations in reservoirs with different cascaded operating modes. Some studies have highlighted differences in water flow regime, depth, particle deposition, transparency, and phytoplankton composition as being responsible for the changes in zooplankton community structure between different types of reservoirs (Nogueira, Oliveira \& Britto, 2008; Perbiche-Neves \& Nogueira, 2010; Okuku et al., 2016). However, in most cases, these studies were focused on a particular group (e.g., copepods) and many lacked long-term research that would have allowed broader conclusions to be made. Understanding how each mode of operation influences zooplankton communities in associated reservoirs can provide a scientific basis for assessing the effects of climate change and anthropogenic impacts on reservoir ecosystems.

An important aspect of this study is that we analyze the major zooplankton groups (rotifers, copepods, and cladocerans) together; an approach that incorporates an important component: the community composition which results from biotic interactions between different zooplankton groups (Eskinazi-Sant'Anna et al., 2013; Beaver et al., 2018). Therefore, zooplankton communities have potential value as indicators of various system properties, including trophic conditions (Garcia-Chicote, Armengol \& Rojo, 2018; Perbiche-Neves et al., 2019). Within this context, the aim of this study was to analyze, over 16 consecutive years, the variability in the zooplankton communities of two cascade reservoirs with different operational modes (storage and run-of-river) located on the Iguaçu River. To achieve these objectives, we correlated various environmental variables and the trophic state indices of the two reservoirs with their zooplankton community structures (richness, abundance, and composition).

It was assumed that the reservoirs and their compartments possessed intrinsic differences that determined their physical and chemical characteristics and zooplankton structure. We tested the hypothesis that the smaller WRT of the run-of-river-operated reservoir was a limiting factor on zooplankton development, and that the species richness and abundance were negatively affected by the increased water flow and decreased trophic conditions downstream of the storage reservoir. Furthermore, the compartmentalization of the storage reservoir was dependent on its more resilient physical characteristics, such as its higher WRT, reservoir size, and depth.

Therefore, we aimed to answer the following questions: (i) Does the upstream reservoir influence the characterization of the zooplankton and the limnological conditions of the downstream 
120

121

122

123

124

125

126

127

128

129

130

131

132

133

134

135

136

137

138

139

140

141

142

143

144

145

146

147

148

149

150

151

152

153

154

155

156

157

158

159

reservoir? (ii) Are the Salto Santiago and Salto Osório reservoirs independent systems? (iii) What are the spatial and temporal dynamics of the zooplankton in the reservoirs?

\section{Materials \& Methods}

\section{Site selection}

The Iguaçu River Basin covers an area of approximately 54,820.4 $\mathrm{km}^{2}$ across the State of Paraná in Brazil (Sema, 2010). The Iguaçu River is a tributary of the Paraná River resulting from the junction of the Iraí and Atuba rivers. The river course follows an east/west direction, with one stretch serving as a natural border between the states of Paraná and Santa Catarina. Another stretch forms the border between Brazil and Argentina. Finally, the Iguaçu River flows into the Paraná River, a few kilometers below the Iguaçu Falls.

This study was conducted at two cascade reservoirs located in the Iguaçu River Basin, southern Brazil (Fig. 1). The Salto Santiago reservoir (storage system) was completed in 1979 and has a watershed area of 43,330 $\mathrm{km}^{2}$ and a reservoir area of $208 \mathrm{~km}^{2}$. The average annual flow is $902 \mathrm{~m}^{3} \mathrm{~s}$, with a cumulative useful volume of 4,094 $\mathrm{hm}^{3}$ and a WRT of 51 days. The sampling sites in the influence area of the reservoir were named S1, S2, S3, and S4. The Salto Osório reservoir (run-of-river system) was completed in 1975 and has a watershed area of 45,800 $\mathrm{km}^{2}$ and a reservoir area of $51 \mathrm{~km}^{2}$. The average annual flow is $937 \mathrm{~m}^{3} \mathrm{~s}$, with a cumulative useful volume of $403 \mathrm{hm}^{3}$ and a WRT of 16 days. The sampling sites in the influence area of the reservoir were named S5, S6, S7, and S8.

Bimonthly sampling was performed between July 2003 and May 2018, and included the winter (May, July, and September) and summer (November, January, and March) periods. The sampling sites were based on water flow characteristics (Thornton, Kimmel \& Payne, 1990), and four environments were identified. These were: (i) the fluvial zone: a lotic environment located upstream of the dam that has a high water flow and is not directly influenced by the reservoir (S1 and S5); (ii) the transitional zone: a lotic/lentic transition environment that is located between the dam and some tributaries. It has moderate water movement that allows the formation of backwater areas (S2 and S6); (iii) the lacustrine zone: an environment located near the dam and has standing or slow water (S3 and S7); and (iv) the downstream zone: a lotic environment downstream of the dam that has a high water flow and is directly influenced by the reservoir (S4 and S8) (Fig. 1).

\section{Sampling and quantification of environmental variables}

Dissolved oxygen ( $\mathrm{mg} \mathrm{L}^{-1}$; portable oximeter, YSI 550A), electrical conductivity $\left(\mu \mathrm{S} \mathrm{cm}^{-1}\right.$; portable conductivity meter, Digimed $\left.{ }^{\circledR} \mathrm{DM}-3 \mathrm{P}\right), \mathrm{pH}$ (portable $\mathrm{pH}$ meter, Digimed ${ }^{\circledR} \mathrm{DM}-2 \mathrm{P}$ ), water temperature $\left(\mathrm{C}^{\circ}\right.$; mercury bulb thermometer), and turbidity (NTU; portable turbidity meter, LaMotte $\left.{ }^{\circledR} 2020 \mathrm{i}\right)$ were measured at the water subsurface in each environment. We also collected water samples from the subsurface with a Van Dorn bottle (2.5 L capacity) to determine other variables: total phosphorus (mg L ${ }^{-1}$; Apha, 2005), total nitrogen ( $\mathrm{mg} \mathrm{L}^{-1}$; Mackereth et al., 1978), total dissolved solids (mg L ${ }^{-1}$; Wetzel \& Likens, 2000), and chlorophyll $a\left(\mu \mathrm{g} \mathrm{L}^{-1}\right.$; 
160

161

162

163

164

165

166

167

168

169

170

171

172

173

174

175

176

177

178

179

180

181

182

183

184

185

186

187

188

189

190

191

192

193

194

195

196

197

198

199

Golterman et al., 1978). Moreover, we determined the maximum depth $\left(\mathrm{Z}_{\max }, \mathrm{m}\right)$ and the transparency of the water column using a Secchi disk $\left(Z_{S D}, m\right)$. In addition, the Agência Nacional das Águas (ANA) provided water flow values $\left(\mathrm{m}^{-3} \mathrm{~s}\right)$ for the lacustrine zone of each reservoir from the hydrological stations located in the dams. Finally, the ANA also provided precipitation values $(\mathrm{mm})$ for the region through the Saudade do Iguaçu weather station.

\section{Sampling, identification, and quantification of the zooplankton}

Zooplankton samples (720 in total) were taken at each site using a conical plankton net with a mesh size of $68 \mu \mathrm{m}$. We filtered 200 liters of subsurface water per sample using a motor-pump. The collected material was placed in polyethylene bottles $(500 \mathrm{~mL})$, labeled, and fixed in $4 \%$ formaldehyde buffered with sodium borate $\left(\mathrm{Na}_{3} \mathrm{BO}_{3}\right)$.

Sedgewick-Rafter chambers were used to quantify the zooplankton. Standardized volume $(50 \mathrm{~mL})$ aliquots were removed from the samples using a Hensen-Stempell pipette $(2.5 \mathrm{~mL})$ and used to count the zooplankton. At least 50 rotifers, cladocerans, young forms (nauplii and copepodites), and adult copepod individuals were counted (modified Bottrell et al., 1976) under an optical microscope with a magnification range of $\times 10$ to $\times 100$. Density was expressed in terms of individuals per $\mathrm{m}^{-3}$. The species were identified using Koste (1978), Reid (1985), Matsumura-Tundisi (1986), and Elmoor-Loureiro (1997). The zooplankton samples were deposited in the Grupo de Pesquisas em Recursos Pesqueiros e Limnologia of the Universidade Estadual do Oeste do Paraná, Campus Toledo, Brazil.

\section{Data analyses}

The trophic state index (TSI) was calculated for each sampling site according to Carlson (1977), as modified by Lamparelli (2004), using the chlorophyll $a$, total phosphorus, and water transparency values. These values were correlated with the zooplankton. A four-way analysis of variance (four-way ANOVA) was used, with a significance level of $P<0.05$, to investigate temporal and spatial changes in zooplankton richness (number of species) and abundance, and the environmental variables. The analyses considered the following factors: year of sampling (2003-18), period (winter and summer), reservoir (SS and SO), and environment (fluvial, transitional, lacustrine, and downstream), as well as the interactions between them (Sokal \& Rohlf, 1991). Normality and homoscedasticity (homogeneity of variance) were initially verified using the Shapiro-Wilk and Levene tests, respectively. When the ANOVA was significant, we used Tukey's post hoc test to investigate the differences between pairs.

We performed a multidimensional non-metric scaling (NMDS) analysis using a Bray-Curtis distance matrix in order to determine the similarities in the zooplankton communities based on density (Oksanen et al., 2016). Young copepod forms (nauplii and copepodites) were not included in the analysis because they generally represent more than one species. The positions of the samples in relation to the year of sampling, period, and environment were used as symbol factors for each reservoir. Stress values were used to determine the number of dimensions. A two-dimensional solution was chosen because there were only small stress value changes in the 
200

201

202

203

204

205

206

207

208

209

210

211

212

213

214

215

216

217

218

219

220

221

222

223

224

225

226

227

228

229

230

231

232

233

234

235

236

237

238

239

sequential dimensions. Subsequently, an analysis of similarity (ANOSIM) was used to verify the statistical significance of the groups identified by the NMDS analysis (Clarke, 1993). In addition, a similarity percentage test (SIMPER) was used to evaluate the contribution of each species to the group separation found by the NMDS analysis (Clarke \& Warwick, 2001).

Finally, a canonical correspondence analysis (CCA) was used to select the predictors that best explained the variation in zooplankton composition. We only used the density data for the species that most contributed to community temporal and spatial variation according to the SIMPER test. The environmental variables were submitted to a stepwise forward selection procedure in which the statistical significance of each variable was tested by the Monte Carlo permutation test (999 permutations) with a cutoff point of $P<0.05$ (Ter-Braak \& Verdonschot, 1995).

All data (except $\mathrm{pH})$ were $\log (x+1)$ transformed prior to analysis to reduce the influence of outliers. The ANOVA, NMDS, ANOSIM, SIMPER, and CCA analyses were performed by the statistical environment in $\mathrm{R}$ version 3.0.2 (R Core Team, 2015) and the Vegan $\mathrm{R}$ version 2.0-6 package (Oksanen et al., 2016).

\section{Results}

\section{Environmental conditions}

A lack of seasonality was observed in the region when the average precipitation values during the study period were evaluated $(P>0.05)$. This indicates that throughout the study period there was no pattern in the rainfall regime, with dry and wet winter and summer periods. In contrast, annual differences in rainfall values were observed $(P<0.05)$, with cumulative rainfall peaks $(>$ $450 \mathrm{~mm}$ ) recorded in November 2005, July 2013, and November 2017. May 2011, and July 2012 and 2017, showed the lowest cumulative rainfall $(<6.0 \mathrm{~mm})$ for the study region. Consequently, this large annual variability in precipitation had a direct effect on reservoir water flow regulation between years $(P<0.05)$. The highest water flow values for both reservoirs were recorded in September 2011 (SS: 2,894 $\mathrm{m}^{-3} \mathrm{~s}$ and SO: 3,036 $\mathrm{m}^{-3} \mathrm{~s}$ ) (Fig. 2).

In general, the reservoirs were classified as mesotrophic according to the TSI classification. The upstream and downstream environments of the dams revealed that there was an increase in average TSI values between 2007 and 2014. However, after 2014 a decrease in TSI values was noticeable, which showed that oligotrophication had occurred (Fig. 3). The TSI values were higher for environments influenced by the SS reservoir. In addition, the TSI only showed an environmental gradient for the SS reservoir, which decreased between the fluvial and lacustrine zones. In contrast the SO reservoir results showed that the environment was homogeneous.

All the environmental variables showed heterogeneity over the years $(P<0.05)$ (Table 1$)$. A table listing the values for each measured variable and the complete four-way ANOVA results is shown in Data S1 and Table S1, respectively. The WT, DO, and TP values were affected by the seasons, with higher WT values in summer, and higher DO and TP values in winter. The environments influenced by the SS reservoir had higher Chl- $a, \mathrm{Z}_{\max }$, and $\mathrm{Z}_{\mathrm{SD}}$ values. In addition, a gradient was observed for the $\mathrm{Z}_{\max }, \mathrm{DO}, \mathrm{pH}$, and $\mathrm{WT}$ values, with a gradual increase between 
240 the fluvial and lacustrine zones in the two reservoirs. However, there were only gradients for the $241 Z_{\mathrm{SD}}$ and Turb values in SS reservoir, with the $Z_{\mathrm{SD}}$ values increasing between the fluvial and

242 lacustrine zones, whereas Turb values decreased. Finally, the Chl- $a$ concentrations were lower

243 downstream compared to the reservoir transitional zones (Table 1).

244

245 General scenario for the zooplankton communities

246 The zooplankton community was composed of 115 taxa. Rotifera were the richest species group

247 (74 species), followed by Cladocera (26 species) and Copepoda (15 species). There was a larger

248

249

250

251

252

253

254

255

256

257

258

259

260

261

262

263

264

265

266

267

268

269

270

271

272

273

274

275

276

277

278

279 number of zooplankton taxa in the environments with lotic characteristics (fluvial and downstream zones) for both reservoirs (Table 2). The frequency (number of samples in which a species occurred) of the different taxa did not show any major changes between environments. In addition, some taxa had a relatively high frequency in the study ( $\geq 70 \%)$, e.g., Polyarthra sp., Bosmina hagmanni, Ceriodaphnia cornuta, Ceriodaphnia silvestrii, Daphnia gessneri, and Notodiaptomus henseni. Young copepod forms (nauplii and copepodits) were more frequent than adult forms (Table 2). The zooplankton community abundances of the two reservoirs were mainly driven by the copepods, which were mainly represented by nauplii and copepodites. However, the most abundant adult species were Calanoids, Notodiaptomus transitans, and $N$. henseni. The cladocerans represented the second most abundant group in the study, particularly C. cornuta and B. hagmanni. Conochilus sp. Asplanchna sieboldii, and Polyarthra sp. were the most abundant rotifer species (Table 2). A table listing the number of taxa found and the abundance values for each zooplankton taxon is shown in Data S2.

\section{Zooplankton richness and abundance}

Significant changes $(P<0.05)$ were observed among the years for total zooplankton species richness and among the different groups in the two reservoirs (Table 3). The results showed that there was a gradual increase in the number of species from 2010, and that rotifers and cladocerans contributed most over the years to the total richness of the zooplankton community (Fig. 4). The total abundance of the zooplankton and the different groups also fluctuated among the years in the two reservoirs (Table 3). The microcrustaceans (copepods and cladocerans) contributed most to community abundance between 2003 and 2012. However, from 2013, the copepods and rotifers were the predominant organisms in the zooplankton (Fig. 4).

There was a small seasonal change in cladoceran richness, with higher values in summer. However, in general, there was no established pattern when all the study years were taken into account (Table 3; Fig. 5). The seasons did affect abundance, with higher values in summer for all groups. However, abundance did not follow a cyclical pattern between the winter and summer periods over the years (Table 3; Fig. 5).

The total species richness, and rotifers and cladocerans species values were higher in the SS reservoir. There were also differences in species richness between the different environments. The fluvial zone had higher total richness values, and the rotifer values were higher in the fluvial-transitional zones. However, there were total species richness differences between the

Peer) reviewing PDF | (2019:10:41833:1:1:NEW 6 Feb 2020) 
280

281

282

283

284

285

286

287

288

289

290

291

292

293

294

295

296

297

298

299

300

301

302

303

304

305

306

307

308

309

310

311

312

313

314

315

316

317

318

319

reservoirs. Species richness was homogeneous in the SS reservoir and heterogeneous in the SO reservoir, with higher values for the fluvial zone compared to downstream (Table 3; Fig. 6).

The results showed that the reservoir abundance values for all zooplankton groups were significantly higher in the SS reservoir. In addition, there were significant changes in abundances between the environments (Table 3 ) because the total abundance and rotifers abundance values upstream of the dams (fluvial, transitional and lacustrine zones), and for microcrustaceans in low flow environments (transitional and lacustrine zones) were higher than in the other zones. There were also differences in copepod abundances and the total abundance of the community between the reservoirs (Table 3). The SS reservoir had greater abundance values upstream of the dam (fluvial-lacustrine zones), whereas the SO reservoir values were higher in the lacustrine zone compared to the higher flow environments (fluvial and downstream zones) (Fig. 6).

\section{Ordination of the zooplankton community}

The NMDS ordination summarized the structure of the zooplankton communities and separated the years and periods for the SS reservoir and the years, periods, and environments for the SO reservoir (Fig. 7). The ANOSIM results also showed that the structure of the zooplankton communities in the two reservoirs were significantly different between years (see Table S2) and between periods. Finally, community structure only changed among the environments in the SO reservoir, where there was a significant difference $(P=0.042)$ between the lacustrine and downstream zone.

According to the SIMPER test, the species that most contributed to the differences in composition between the sampling years (2003-18) were Polyarthra sp. (11.0\%), C. cornuta (10.6\%), and Conochilus sp. (10.4\%) in the SS reservoir; and C. cornuta (13.1\%), B. hagmanni (9.2\%), and Ceriodaphnia silvestrii (8.7\%) were the most representative in the SO reservoir. The species that contributed the most to the differences in composition between the winter and summer periods were the same as for the sampling years, but with different contribution percentages. The species that contributed the most to the period differences were C. cornuta (11.3\%), Conochilus sp. (10.4\%) and Polyarthra sp. (10.1\%) in the SS reservoir; and C. cornuta (13.5\%), B. hagmanni (9.0\%), and C. silvestrii (8.7\%) in the SO reservoir, (Table 4). It was possible to clearly discern temporal changes in zooplankton composition and the results showed that there was species substitution over time (Fig. 8). Finally, zooplankton composition differences among the environments only occurred in the SO reservoir. The species that contributed most to the differences were C. cornuta (13.1\%), B. hagmanni (9.1\%), and $C$. silvestrii $(8.7 \%)$ (Table 4).

\section{Relationships between zooplankton community dynamics and the environmental variables} The first two CCA axes for the SS reservoir were significant $(P=0.001)$ and together explained $84.6 \%$ of the total variability in the zooplankton data. The first two axes of the CCA were also significant $(P=0.001)$ for the SO reservoir and together explained $73.8 \%$ of the total variability in the zooplankton data (Fig. 9). The first axes of the CCAs expressed differences between the 
320

321

322

323

324

325

326

327

328

329

330

331

332

333

334

335

336

337

338

339

340

341

342

343

344

345

346

347

348

349

350

351

352

353

354

355

356

357

358

359

years of study for the two reservoirs. Between the years 2003 and 2012, some rotifers (e.g., Euchlanis dilatata and Trichocerca cylindrica) and microcrustaceans (D. gessneri, B. hagmanni, and $N$. transitans) were strongly associated with high electrical conductivity, $\mathrm{Z}_{\mathrm{SD}}$, WT, and the TP concentration. In contrast, the years 2013-18 were characterized by higher turbidity and higher Chl- $a$, TDS, and NT concentrations, which were mainly associated with small rotifers (e.g., Kellicottia bostoniensis, Conochilus sp., and Polyarthra sp.).

The second axes of the CCAs were related to the winter and summer periods in the reservoirs. The WT and Chl- $a$ and TDS concentrations were elevated in summer, which favored species such as Asplanchna sieboldii, Conochilus sp., Moina minuta, Diaphanosoma spinulosum, and $N$. henseni. In contrast, the higher $\mathrm{Z}_{\mathrm{SD}}$, and $\mathrm{TP}$, and $\mathrm{DO}$ concentrations in winter favored some rotifer species (e.g., K. bostoniensis and Polyarthra sp.) and microcrustaceans (e.g., Thermocyclops decipiens, D. gessneri, and B. hagmanni) (Fig. 9).

\section{Discussion}

\section{Water characteristics of the two reservoirs}

In the long-term, the rainfall patterns show a trend of low and/or absent seasonality for the study region. Consequently, there were few seasonal changes (except for DO, temperature, and TP) in the water characteristics. In addition, the lack of seasonality in the water properties may also be associated with the characteristics of the reservoirs, which are manipulated according to their operational needs. Reservoirs temporarily accumulate rainwater that is gradually released. This process delays and mitigates flow peaks, which means that, in contrast to rivers, reservoirs do not follow a seasonal pattern (Ravazzani et al., 2014; Ignatius \& Rasmussen, 2016). Even run-ofriver reservoirs, such as SO, show large changes in their flow regime that are inconsistent with natural regimes (Baumgartner, Baumgartner \& Gomes, 2017). Furthermore, the lack of seasonality in the SO reservoir may be closely linked to the operational needs of the upstream SS reservoir, which has a major influence on the flow regime.

The results showed that the inter-annual changes in rainfall and water temperature contributed to the large annual variability in the physical and chemical characteristics of the water. Inter-annual climatic phenomena, such as El niño, directly act on the amplitude of meteorological events, such as precipitation. This means that they can modify water properties, which may include changes in dissolved oxygen concentration, transparency, stratification, and primary productivity (O'Reilly et al., 2003; Verburg, Hecky \& King, 2003; Jankowski et al., 2006; Hampton et al., 2008; Marcé et al., 2010), etc. Most previous studies related these modifications to changes in reservoir water flow, and the thermal balance and mixing dynamics of water bodies.

The high values for Chl- $a$ and TSI in the storage reservoir (SS) may be linked to the long WRT and the large number of tributaries that drain into the SS, some of which drain urban areas, which means that they carry a large amount of nutrients. WRT is a determining factor in stratification processes and nutrient availability, promoting phytoplankton development as a consequence of higher nutrient concentrations and water column stability (Londe et al., 2016). In 
360

361

362

363

364

365

366

367

368

369

370

371

372

373

374

375

376

377

378

379

380

381

382

383

384

385

386

387

388

389

390

391

392

393

394

395

396

397

398

399

addition, the cascading effects of the reservoirs promote changes in the aquatic environment. The storage reservoir releases more transparent waters with low concentrations of suspended solids because most of the sediment is retained in the upstream compartments (Ney, 1996; Padisák, Köhler \& Hoeg, 1999). This can lead to downstream oligotrophication. These changes in the longitudinal gradients of a reservoir cascade are predicted by the "cascading reservoir continuum concept" (Barbosa et al., 1999).

The differences in terms of size, morphometry, and the WRT between the two reservoirs also explain the extent to which tributaries influence reservoirs. The modifications due to tributary entrances in run-of-river reservoirs are smaller and are associated with semi-lotic conditions (Nogueira, Perbiche-Neves \& Naliato, 2012). Furthermore, there is not enough time or distance for sediment loads to be deposited on the reservoir bed, and the simple SO reservoir morphometry does not favor the particle deposition process (Perbiche-Neves \& Nogueira, 2010). The opposite situation occurs in SS reservoir, due to its dendritic shape and long longitudinal axis, which allows particle sedimentation and a longitudinal increase in transparency. This characteristic corroborates the foreseeable modifications towards the dam zone (Thornton, Kimmel \& Payne, 1990; Pinto-Coelho et al., 2006; Soares et al., 2012). These are due to reduced water velocity, and increased depth and WRT. The WRT is a fundamental variable for reservoir ecology, which interferes with physical, chemical, and biological characteristics, and depends on the interaction between different factors, such as precipitation, flow, evaporation, and infiltration (Nogueira, Perbiche-Neves \& Naliato, 2012; Beaver et al., 2013).

\section{Zooplankton community structure and temporal variation in the two reservoirs}

Simultaneous extreme weather events, such as heavy rainfall and flooding, and severe droughts, have been affecting South America in recent years (Rocha et al., 2019). These opposite extreme events may have affected both reservoirs between 2003-18, leading to significant changes in nutrient loading with complex effects on zooplankton structuring. The zooplankton structure (richness, abundance, and composition) underwent important changes, some of which coincided with increased nutrient loading and trophic state changes in the reservoirs. The decrease in the abundance of large zooplankton filter-feeding species, such as large rotifers (e.g., Brachionus calyciflorus and Euchlanis dilatata), cladocerans (e.g., D. gessneri) and calanoid copepods ( $N$. transitans), coincided with an increase in the abundance of other species, such as the rotifer $A$. sieboldii, small rotifers with generalist characteristics (e.g., Conochilus sp. and Polyarthra sp.,) and small cladocerans (e.g., B. hagmanni and C. cornuta).

The use of zooplankton species as biological indicators can provide important information about current and past processes, such as changes in biological relationships and in the physical and chemical properties of water (Perbiche-Neves et al., 2019). For example, the cladoceran $D$. gessneri and calanoid copepods were abundant in the years with higher water transparency and lower concentrations of Chl- $a$ and TDS (2003-12). The filter-feeding activity of these microcrustaceans can have a great influence on Secchi transparency values (Garcia-Chicote, Armengol \& Rojo, 2018), as they are able to eliminate nanoplankton in a large area of the water. 
400 Concentrations of small particles (e.g., nanoplankton) affect Secchi depth values to a greater 401 extent than those of larger particles (Horn \& Horn, 1995), resulting in greater Secchi depths in 402 the years when there were high abundances of daphinids and calanoid copepods. In contrast, 403 young copepod forms (nauplii and copepodites) and small cladocerans (B. hagmanni and $C$.

404

405

406

407

408

409

410

411

412

413

414

415

416

417

418

419

420

421

422

423

424

425

426

427

428

429

430

431

432

433

434

435

436

437

438

439 cornuta), which were mainly observed between $2007-14$, indicate that mesotrophic conditions prevailed in both reservoirs. Environments with higher concentrations of detritus and nutrients (mesotrophic) favor the growth of bacteria and protozoa, an important source of food for small filter-feeders such as nauplii, rotifers, and small cladocerans (bosminids) (Brito, Maia-Barbosa \& Pinto-Coelho, 2011). In addition, nutrient enrichment in reservoirs may indicate the appearance of cyanobacteria in the phytoplankton. Reports of cyanobacterial blooms in oligomesotrophic reservoirs are not uncommon (Brito, Maia-Barbosa \& Pinto-Coelho, 2011; Su et al., 2019). Some previous studies in the SS and SO reservoirs have also recorded large abundances of cyanobacteria in the phytoplankton (Adloff et al., 2018; Bortolini et al., 2018). The filaments or mucilages of these algae directly interfere with the filtration apparatuses of large cladocerans and calanoid copepods, which leads to the decline and replacement of these populations by small rotifers and cladocerans (Sendacz, Caleffi \& Santos-Soares, 2006; EskinaziSant'Anna et al., 2013; Perbiche-Neves et al., 2016). In addition, a greater abundance of young copepod stages than adults may indicate an adaptive strategy to compensate for the high mortality of young stages (Lansac-Tôha, Bonecker \& Velho, 2005).

In both reservoirs, rotifers were the organisms that most contributed to the total species richness of the zooplankton. The high diversity of this group in reservoirs has been a recurring pattern in Brazil and is mainly attributed to the opportunistic characteristics of this group. Rotifers occupy a wide range of water bodies, have a wide food spectrum (from bacteria to filamentous algae), have a high population turnover rate, and are more diverse in the littoral areas of oligo-mesotrophic water bodies (Segers, 2008). Some studies have associated the presence of certain rotifer species with the trophic conditions of the environments in which they are found. For example, Nogueira (2001) and Sampaio et al. (2002) related the presence of the rotifers Polyarthra sp. and Conochilus sp. with the oligotrophic conditions of Paranapanema River reservoirs. In this study, these species were predominant in the reservoirs mainly during the last few years (starting in 2013), when the waters were more oligotrophic. In addition, the increase in the abundance of the rotifer $A$. sieboldii in these years, especially in the SS reservoir, coincided with an increase in the abundance of these small rotifers, and in the concentrations of Chl- $a$ and TDS. The genus Asplanchna are considered voracious predators, usually cannibals, and can feed on almost all species of rotifers, in addition to consuming phytoplankton and detritus (Gilbert, 1980; Thatcher et al., 1993). Choi et al. (2015) observed that the preferred prey of Asplanchna sp. is pelagic rotifers of the genera Polyarthra and Keratella. Thus, the interannual variations in trophic conditions also played an important role in increasing A. sieboldii populations, owing to the greater availability of prey. In this context, knowledge of zooplankton fluctuations, both seasonal and inter-annual, is essential to assess the effects of climate change on nutrient transfer processes in aquatic food networks (Caroni \& Irvine, 2010; García-Chicote, 
440 Armengol \& Rojo, 2018). Therefore, from an ecological point of view, zooplankton plays an

441

442

443

444

445

446

447

448

449

450

451

452

453

454

455

456

457

458

459

460

461

462

463

464

465

466

467

468

469

470

471

472

473

474

475

476

477

478

479

essential role within the trophic networks of lakes and reservoirs, as it has high value as an indicator that cannot be replaced by phytoplankton and fish studies (Jeppesen et al., 2011).

The results for seasonal changes in the attributes of zooplankton communities showed that only species richness did not change. The low seasonal fluctuations in rainfall and reservoir flow patterns probably contributed to the richness homogeneity between the periods. In contrast, there were seasonal changes in abundance and species composition. The fall in abundance values during winter was mainly linked to the decrease in water temperature. Changes in temperature can trigger seasonal processes that influence zooplankton directly (e.g., metabolic rates, body size, egg production) and indirectly (e.g., phytoplankton structure) (Hart \& Bychek, 2011; Brito, Maia-Barbosa \& Pinto-Coelho, 2016). Other studies have also observed a decrease in zooplankton abundance in tropical reservoirs during periods with lower temperatures (Sendacz, Caleffi \& Santos-Soares, 2006; Tundisi, Matsumura-Tundisi \& Abe, 2008; Sartori et al., 2009). In temperate lakes, there is a noticeable decrease in zooplankton abundance during winter and an increase in the abundance of new species during warmer periods (spring and summer) (Hessen et al., 2006; Beaver et al., 2013). It is probable that harsh winters in southern Brazil are an important regulator of zooplankton community structure.

The rotifers Synchaeta sp., Polyarthra sp., and K. bostoniensis (an invasive species originating in North America) were predominant during the winter periods between 2013 and 2018, and had a strong relationship with decreasing water temperature and increased turbidity in the SS reservoir, and the TN concentrations in both reservoirs. Some rotifers exhibit a moderate tolerance to temperature variation and are common in nutrient-rich environments where they efficiently consume solid suspended particles and colloids from bacteria that break down organic matter (Sluss, Cobbs \& Thorp, 2008; Balkić et al., 2016). However, during the summer periods of the same years, the copepod $N$. henseni and the cladoceran $D$. spinulosum were more abundant in both reservoirs. The evaluated data indicated that, besides the temperature, the higher food availability (Chl- $a$ and TDS) was also responsible for the increase in these organisms. Therefore, higher summer temperatures may have favored higher phytoplankton productivity, which led to favorable conditions for the development of these populations. The cyclopoid copepod $T$. decipiens was common in the zooplankton during the winter periods. Cyclopoid copepods preferably consume algae and, additionally, other invertebrates present in zooplankton or in the benthic and littoral areas (Dussart \& Defaye, 1995; Velho, Lansac-Tôha \& Bonecker, 2005;

Perbiche-Neves et al., 2016). The lower winter temperatures did not limit the development of $T$. decipiens because it has a wide food spectrum.

During the winter periods between the years 2003-12, there was also a clear increase in the populations of microcrustaceans B. hagmanni, D. gessneri, C. cornuta, and N. transitans in both reservoirs. The interactions among factors such as decreased transparency, competition for resources, and fish predation pressure may have limited the development of these winter favored populations in the summer. Like phytoplankton, zooplankton have characteristic seasonal cycles that are strongly linked to temperature seasonality, hydrology, food availability, and predation

Peer) reviewing PDF | (2019:10:41833:1:1:NEW 6 Feb 2020) 
480 pressure, and variations in these factors can affect the populations of these organisms (Havens et 481 al., 2009; Beaver et al., 2018; Hu et al., 2019). However, previous studies (e.g., Havens, 2002; 482 Pinto-Coelho et al., 2005) and our results indicate that there appears to be a greater correlation 483 between microcrustaceans and TP concentrations than between microcrustaceans and Chl $a$ in 484 the SS reservoir. Sometimes the primary productivity of algae is lower than the secondary 485 productivity of zooplankton. Similarly, primary productivity by algae may not cover the high 486 rates of assimilation by zooplankton. At this point, the zooplankton probably begin to consume 487 suspended detritus or bacterioplankton. When this happens, TP may be a better indicator of food 488 availability and better able to explain zooplankton variability than Chl-a (Havens, 2002; Pinto489 Coelho et al., 2005; Sluss, Cobbs \& Thorp, 2008).

Studies on the functioning and structure of zooplankton communities in reservoir ecosystems offer opportunities to investigate patterns of response to cyclical variations and episodic disturbances. An understanding of planktonic dynamics in reservoirs can also be useful to assess the resilience of this type of ecosystem over relatively short periods, which can present profound changes in the intra- and inter-reservoir limnological conditions arranged in the cascade. This dynamic is generated by short-term variations in the flow regime, water level, and WRT and by interactions with other aquatic and terrestrial organisms present in the hydrographic basin (Barbosa et al., 1999; Nogueira, 2001).

\section{Zooplankton differences between the two reservoir environments}

The characterization of the zooplankton community and its spatial distribution provide important data for the study of reservoirs, facilitating a broader understanding of these environments and allowing for adequate monitoring and management (Nogueira, 2001; Bernot et al., 2004). The zooplankton richness, composition, and abundance results showed that there were differences between the reservoirs. The higher richness and abundance in SS were probably related to the higher phytoplankton productivity, which was indicated by the higher Chl- $a$ and TSI values. Some previous studies have suggested that there was also a strong link between the zooplankton community and the functional characteristics of the reservoirs (Bini et al., 2008; Nogueira, Oliveira \& Britto, 2008). They suggested that the degree of compartmentalization, stability of the different water masses, and the presence of vertical stratification had crucial effects on zooplankton community structure. For example, they can lead to an increase in the richness and abundance values (Beaver et al., 2015). Furthermore, a low WRT has been shown to be an important factor that limits zooplankton abundances in many run-of-river reservoirs (e.g., Perbiche-Neves \& Nogueira, 2013; Beaver et al., 2013).

The longitudinal total richness of the zooplankton was not the same in the two reservoirs. Only the SO reservoir showed heterogeneity for this attribute, with a higher number of species in the fluvial zone compared to downstream. The higher number of species in the fluvial zone of the SO reservoir may be related to species increments from the SS reservoir, especially planktonic species that are derived from the lacustrine zone. However, the homogeneous distribution of richness in the SS reservoir may be related to its improved stability. Only the 
520 rotifers exhibited a longitudinal gradient for richness, with a greater number of species in the 521 fluvial and transitional zones. The greater number of species in these environments may be 522 related to the higher current velocity and the lower depth compared to the lacustrine zone. These 523 factors would increase transportation to the water column of species from the littoral and benthic 524 areas (Serafim-Jr. et al., 2016). Some studies have also reported greater rotifer richness in the 525 fluvial and transitional zones. They attributed this to the incorporation of non-planktonic and 526 planktonic species from lateral tributaries and reservoirs located upstream of the channel, 527 respectively (Marzolf, 1990; Velho, Lansac-Tôha \& Bonecker, 2005; Czerniawski \& Kowalska528 Góralska, 2018).

529 The abundance values also showed a longitudinal gradient in both reservoirs, with higher 530 values in environments with lentic characteristics. The largest zooplankton abundances, 531 especially microcrustaceans, occurred in the transitional and lacustrine environments, and this

532

533

534

535

536

537

538

539 may be related to the lower flow velocity and turbidity, and higher values for water transparency, dissolved oxygen, and primary productivity in these compartments (Hart, 2004; Sartori et al., 2009; Brito, Maia-Barbosa \& Pinto-Coelho, 2016). When flow velocity is high, zooplankton population growth can be inhibited, even when food resource levels are high (Beaver et al., 2015). The greater depth in these compartments may also benefit the development of species with vertical migration behavior, such as microcrustaceans (Perbiche-Neves \& Nogueira, 2013).

Longitudinal changes in species composition were only observed in the SO reservoir where

540 the main differences were between the lacustrine and downstream zones. The WRT differences

541 influence the limnological characteristics and dynamics of aquatic communities within reservoirs and in areas downstream of the dams (Ferrareze, Casatti \& Nogueira, 2014). Therefore, the flow

542 velocity in the channel below the two types of reservoirs will also differ and will differentially

543

544 influence downstream species composition. The SIMPER test results showed that the cladoceran

545 species, especially bosminids and daphinids, contributed most to differences among the environments. These microcrustaceans have planktonic characteristics and do not adapt well to the unstable conditions present in lotic environments, such as downstream of the SO reservoir. They mainly prefer places with slow or standing water (Viroux, 2002). Several studies have suggested that there is a larger decrease in cladoceran populations in lotic environments than

550

551

552

553

554

555

556

557

558

559 small rotifer populations, which is probably caused by high mortality rates due to turbulence, and limitations to growth and reproduction (Baranyi et al., 2002; Sluss, Cobbs \& Thorp, 2008). In addition, the type of filtration feeding has been cited as one of the factors that make these cladoceran species so successful in lentic environments.

\section{Conclusions}

The WRT seems to play an important role in zooplankton community structure in this cascade system and is directly linked to the functional characteristics of the reservoirs. The greater stability of the water masses and higher primary productivity in the storage reservoir (SS) provide a more suitable environment for the development of zooplankton populations, mainly microcrustaceans. In contrast, the location (downstream) and shorter WRT of the run-of-river 
560 reservoir (SO) negatively affects species richness and zooplankton abundance, because they 561 decrease trophic conditions and increase water flow, respectively. The SS reservoir (upstream) 562 influences the limnological and biological characterization of the SO reservoir (downstream), 563 mainly owing to the release of more oligotrophic waters and the high export rates of zooplankton 564 downstream, making the downstream reservoir dependent on the water level management actions 565 of the upstream reservoir. In contrast, the SS reservoir is more dependent on its intrinsic 566 characteristics (e.g., its longitudinal axis and depth), which provide for the formation of 567 environmental gradients that act directly on the zooplankton structure. Thus, these differences

568

569

570

571

572

573

574

575

576

577

578

579

580

581

582

583

584

585

586

587

588

589

590

591

592

593

594

595

596

597 between the reservoirs result in changes both in water characteristics and in the structure of the zooplankton community throughout the cascade system. Annual and seasonal changes in water quality and water flow displayed equally important effects on the temporal variation in the zooplankton structures in both reservoirs, and it was possible to observe species substitutions over time. Despite their important ecological role in aquatic systems, few environmental policies consider zooplankton as a tool to strengthen strategies for managing and maintaining the biological diversity of these environments. These results support the utilization of these organisms as a useful tool to improve our understanding of changes in water quality and the ecosystem processes involved in these changes.

\section{Acknowledgements}

We would like to thank the GERPEL (Grupo de Pesquisas em Recursos Pesqueiros e Limnologia), INEO (Instituto Neotropical de Pesquisas Ambientais), and UNIOESTE (Universidade Estadual do Oeste do Paraná) for providing technical support. We are also grateful to the anonymous reviewers, whose detailed comments and constructive suggestions improved the quality of the manuscript.

\section{References}

Adloff CT, Bem CC, Reichert G, Azevedo JCR. 2018. Analysis of the phytoplankton community emphasizing cyanobacteria in four cascade reservoirs system of the Iguazu River, Paraná, Brazil. Brazilian Journal of Water Resources 23:e6 DOI 10.1590/23180331.0318170050 .

Agostinho AA, Gomes LC, Santos NCL, Ortega JCG, Pelicice FM. 2016. Fish assemblages in Neotropical reservoirs: colonization patterns, impacts and management. Fisheries Research 173:26-36 DOI 10.1016/j.fishres.2015.04.006.

Apha-American Public Health Association. 2005. Standard Methods for the Examination Water and Wastewater. Washington: APHA.

Balkić AG, Ternjej I, Špoljar M. 2016. Hydrology driven changes in the rotifer trophic structure and implications for food web interactions. Ecohydrology 11:e1917 DOI 10.1002/eco.1917. 
598

599

600

601

602

603

604

605

606

607

608

609

610

611

612

613

614

615

616

617

618

619

620

621

622

623

624

625

626

627

628

629

630

631

632

633

634

635

636

Baranyi C, Hein T, Holarek C, Keckeis S, Schiemer F. 2002. Zooplankton biomass and community structure in a Danube River floodplain system: effects of hydrology. Freshwater Biology 47:473-82 DOI 10.1046/j.1365-2427.2002.00822.x.

Barbosa FAR, Padisák J, Espindola ELG, Borics G, Rocha O. 1999. The cascading reservoir continuum concept (CRCC) and its application to the River Tietê, São Paulo State, Brazil. In: Tundisi JG, Straškraba M, eds. Theoretical reservoir ecology and its applications. São Carlos: Backhuys Publishers, 425-437.

Baumgartner MT, Baumgartner G, Gomes LC. 2017. The effects of rapid water level changes on fish assemblages: the case of a spillway gate collapse in a Neotropical reservoir. River Research and Applications 33:548-557 DOI 10.1002/rra.3110.

Baumgartner MT, Piana PA, Baumgartner G, Gomes LC. 2019. Storage or run-of-river reservoirs: exploring the ecological effects of dam operation on stability and species interactions of fish assemblages. Environmental Management DOI 10.1007/s00267-01901243-x.

Baxter RM. 1977. Environmental effects of dams and impoundments. Annual Review of Ecology and Systematics 8:255-283 DOI 10.1146/annurev.es.08.110177.001351.

Beaver JR, Jensen DE, Casamatta DA, Tausz CE, Scotese KC, Buccier KM, Teacher CE, Rosati TC, Minerovic AD, Renicker TR. 2013. Response of phytoplankton and zooplankton communities in six reservoirs of the middle Missouri River (USA) to drought conditions and major flood event. Hydrobiologia 705:173-189 DOI 10.1007/s10750-0121397-1.

Beaver JR, Scotese KC, Manis EE, Juul STJ, Carroll J, Renicker TR. 2015. Variation in water residence time is the primary determinant of phytoplankton and zooplankton composition in a Pacific Northwest reservoir ecosystem (Lower Snake River, USA). River Systems 21:241-255 DOI 10.1127/rs/2015/0100.

Beaver JR, Kirsch JE, Tausz CE, Samples EE, Renicker TR, Scotese KC, McMaster HA, Blasius-Wert BJ, Zimba PV, Casamatta DA. 2018. Long-term trends in seasonal plankton dynamics in Lake Mead (Nevada-Arizona, USA) and implications for climate change. Hydrobiologia 822:85-109 DOI 10.1007/s10750-018-3638-4.

Bernot RJ, Dodds WK, Quist MC, Guy CS. 2004. Spatial and temporal variability of zooplankton in a great plains reservoir. Hydrobiologia 525:101-112 DOI 10.1023/B:HYDR.0000038857.19342.fd.

Biggs BJF, Nikora VI, Snelder TH. 2005. Linking scales of flow variability to lotic ecosystem structure and function. River Research and Applications 21:283-298 DOI 10.1002/rra.847.

Bini LM, Silva LCF, Velho LFM, Bonecker CC, Lansac-Tôha FA. 2008. Zooplankton assemblages concordance patterns in Brazilian reservoirs. Hydrobiologia 598:247-255 DOI 10.1007/s10750-007-9157-3.

Bortolini JC, Silva PRL, Baumgartner G, Bueno NC. 2018. Response to environmental, spatial, and temporal mechanisms of the phytoplankton metacommunity: comparing 
637

638

639

640

641

642

643

644

645

646

647

648

649

650

651

652

653

654

655

656

657

658

659

660

661

662

663

664

665

666

667

668

669

670

671

672

673

674

675

ecological approaches in subtropical reservoirs. Hydrobiologia 830:45-61 DOI 10.1007/s10750-018-3849-8.

\section{Bottrell HH, Duncan A, Gliwicz Z, Grygierek E, Herzig A, Hillbricht-Illkowska A,} Kuruasawa H, Larsson P, Weglenska T. 1976. A review of some problems in zooplankton production studies. Norwegian Journal Zoology 24:419-456.

Brito SL, Maia-Barbosa PM, Pinto-Coelho RM. 2011. Zooplankton as an indicator of trophic conditions in two large reservoirs in Brazil. Lakes \& Reservoirs: Research \& Management 16:253-264 DOI 10.1111/j.1440-1770.2011.00484.x.

Brito SL, Maia-Barbosa PM, Pinto-Coelho RM. 2016. Secondary productivity of main microcrustacean species of two tropical reservoirs in Brazil and its relationship with trophic state. Journal of Limnology 75:320-329 DOI 10.4081/jlimnol.2016.1267.

Carlson RE. 1977. A trophic state index for lakes. Limnology and Oceanography 22:361-369 DOI 10.4319/10.1977.22.2.0361.

Caroni R, Irvine K. 2010. The potential of zooplankton communities for ecological assessment of lakes: redundant concept or political oversight? Biology \& Environment Proceedings of the Royal Irish Academy 110:35-53 DOI 10.3318/BIOE.2010.110.1.35.

Cella-Ribeiro A, Doria CRC, Dutka-Gianelli J, Alves H, Torrente-Vilara G. 2017. Temporal fish community responses to two cascade run-of-river dams in the Madeira River, Amazon basin. Ecohydrology 10:e1889 DOI 10.1002/eco.1889.

Choi JY, Jeong KS, La GH, Chang KH, Joo GJ. 2015. The influence of aquatic macrophytes on the distribution and feeding habits of two Asplanchna species (A. priodonta and $A$. herrickii) in shallow wetlands in South Korea. Journal of Limnology 74:1-11 DOI $0.4081 /$ jlimnol.2014.896.

Clarke KR. 1993. Non-parametric multivariate analyses of changes in community structure. Austral Ecology 18:117-143 DOI 10.1111/j.1442-9993.1993.tb00438.x.

Clarke KR, Warwick RM. 2001. Change in marine communities: an approach to statistical analysis and interpretation. Plymouth: PRIMER-E.

Czerniawski R, Kowalska-Góralska M. 2018. Spatial changes in zooplankton communities in a strong human-mediated river ecosystem. Peerj 6:e5087 DOI 10.7717/peerj.5087.

Dussart BH, Defaye D. 1995. Copepoda: introduction to the Copepoda. The Hague: SPB Academic Publishing.

EImoor-Loureiro LMA. 1997. Manual de identificação de cladóceros límnicos do Brasil. Brasília: Universa.

Eskinazi-Sant'Anna EM, Menezes R, Costa IS, Araújo M, Panosso R, Attayde JL. 2013. Zooplankton assemblages in eutrophic reservoirs of the Brazilian semi-arid. Brazilian Journal of Biology 73:37-52 DOI 10.1590/S1519-69842013000100006.

Ferrareze M, Casatti L, Nogueira MG. 2014. Spatial heterogeneity affecting fish fauna in cascade reservoirs of the Upper Paraná Basin, Brazil. Hydrobiologia 738:97-109 DOI 10.1007/S10750-014-1922-5.

Peer] reviewing PDF | (2019:10:41833:1:1:NEW 6 Feb 2020) 
676 García-Chicote J, Armengol X, Rojo C. 2018. Zooplankton abundance: a neglected key

677

678

679

680

681

682

683

684

685

686

687

688

689

690

691

692

693

694

695

696

697

698

699

700

701

702

703

704

705

706

707

708

709

710

711

712

713

714

715 element in the evaluation of reservoir water quality. Limnologica 69:46-54 DOI 10.1016/j.limno.2017.11.004.

Gilbert JJ. 1980. Feeding in the rotifer Asplanchna: behavior, cannibalism, selectivity, prey defenses, and impact on rotifer communities. In: Kerfoot WC, ed. Evolution and ecology of zooplankton communities. Hanover: University Press of New England, 158-172.

Golterman HL, Clyno RS, Ohnstad MAM. 1978. Methods for physical and chemical analysis of freshwaters. Oxford: Blackwell.

Hampton SE, Izmest'eva LR, Moore MV, Katz SL, Dennis B, Silow EA. 2008. Sixty years of environmental change in the world's largest freshwater lake - Lake Baikal, Siberia. Global Change Biology 14:1947-1958 DOI 10.1111/j.1365-2486.2008.01616.x.

Hart RC. 2004. Cladoceran periodicity patterns in relation to selected environmental factors in two cascading warm-water reservoir over a decade. Hydrobiologia 526:99-117 DOI 10.1023/B:HYDR.0000041610.56021.63.

Hart RC, Bychek EA. 2011. Body size in freshwater planktonic crustaceans: an overview of extrinsic determinants and modifying influences of biotic interactions. Hydrobiologia 668:61-108 DOI 10.1007/s10750-010-0400-y.

Havens KE. 2002. Zooplankton structure and potential food web interactions in the plankton of a subtropical chain-of-lakes. The Scientific World Journal 2:926-942 DOI 10.1100/tsw.2002.171.

Havens KE, Elia A, Taticchi M, Fulton R. 2009. Zooplankton-phytoplankton relationships in shallow subtropical versus temperate lakes Apopka (Florida, USA) and Trasimeno (Umbria, Italy). Hydrobiologia 628:165-175 DOI 10.1007/s10750-009-9754-4.

Hessen DO, Faafeng BA, Smith VH, Bakkestuen VB, Walsen B. 2006. Extrinsic and intrinsic controls of zooplankton diversity in lakes. Ecology 87:433-443 DOI 10.1890/05-0352.

Horn W, Horn H. 1995. Interrelationships between crustacean zooplankton and phytoplankton: results from 15 years of field observations at the mesotrophic Saidenbach Reservoir (Germany). Hydrobiologia 307:231-238 DOI 10.1007/BF00032017.

Hu B, Hu X, Nie X, Zhang X, Wu N, Hong Y, Qin HM. 2019. Seasonal and inter-annual community structure characteristics of zooplankton driven by water environment factors in a sub-lake of Lake Poyang, China. Peerj 7:e7590 DOI 10.7717/peerj.7590.

Ignatius AR, Rasmussen TC. 2016. Small reservoir effects on headwater water quality in the rural-urban fringe, Georgia Piedmont, USA. Journal of Hydrology: Regional Studies 8:145161 DOI 10.1016/j.ejrh.2016.08.005.

Jankowski T, Livingstone DM, Bührer H, Forster R, Niederhauser P. 2006. Consequences of the 2003 European heat wave for lake temperature profiles, thermal stability, and hypolimnetic oxygen depletion: implications for a warmer world. Limnology and Oceanography 51:815-819 DOI 10.4319/1o.2006.51.2.0815.

Jeppesen E, Nõges P, Davidson TA, Haberman J, Nõges T, Blank K, Lauridsen TL, Søndergaard M, Sayer C, Laugaste R, Johansson LS, Bjerring R, Amsinck SL. 2011. 
716

717

718

719

720

721

722

723

724

725

726

727

728

729

730

731

732

733

734

735

736

737

738

739

740

741

742

743

744

745

746

747

748

749

750

751

752

753

754

Zooplankton as indicators in lakes: a scientific-based plea for including zooplankton in the ecological quality assessment of lakes according to the European Water Framework
Directive (WFD). Hydrobiologia 676:279 DOI 10.1007/s10750-011-0831-0.

Koste W. 1978. Rotatoria Die Rädertiere Mitteleuropas begründet von Max Voigt Monogononta. Berlin: Gebrüder Borntraeger.

Lamparelli MC. 2004. Grau de trofia em corpos d'água do estado de São Paulo: avaliação dos métodos de monitoramento. D. Phil. Thesis, Universidade de São Paulo.

Lansac-Tôha FA, Bonecker CC, Velho LFM. 2005. Estrutura da comunidade zooplanctônica em reservatórios. In: Rodrigues L, Thomaz SM, Agostinho AA, Gomes LC, eds. Biocenoses em reservatórios: padrões espaciais e temporais. São Carlos: RiMa, 115-127.

Loken LC, Crawford JT, Dornblaser MM, Striegl RG, Houser JN, Turner PA, Stanley EH. 2018. Limited nitrate retention capacity in the Upper Mississippi River. Environmental Research Letters 13:074030 DOI 10.1088/1748-932/aacd51.

Londe LR, Novo EMLM, Barbosa C, Araujo CAS. 2016. Water residence time affecting phytoplankton blooms: study case in Ibitinga Reservoir (São Paulo, Brazil) using Landsat/TM images. Brazilian Journal of Biology 76:664-672 DOI 10.1590/15196984.23814.

Mackereth FJH, Heron J, Talling JF. 1978. Water analysis: some revised methods for limnologists. Internationale Revue der gesamten Hydrobiologie und Hydrographie 64:456456 DOI 10.1002/iroh.19790640404.

Marcé R, Rodríguez-Arias MA, García JC, Armengol J. 2010. El niño Southern Oscillation and climate trends impact reservoir water quality. Global Change Biology 16:2857-2865 DOI 10.1111/j.1365-2486.2010.02163.x.

Marzolf, GR. 1990. Reservoirs as environments for zooplankton. In: Thornton KW, Kimmel BL, Payne FE, eds. Reservoir limnology: ecological perspectives. New York: John Wiley \& Sons, 195-208.

Matsumura-Tundisi T. 1986. Latitudinal distribution of Calanoida copepods in freshwater aquatic systems of Brazil. Brazilian Journal of Biology 46:527-553.

McManamay RA, Oigbokie CO, Kao SC, Bevelhimer MS. 2016. Classification of us hydropower dams by their modes of operation. River Research and Applications 32:14501468 DOI 10.1002/rra.3004.

Ney JJ. 1996. Oligotrophication and its discontents: effects of reduced nutrient loading on reservoir fisheries. American Fisheries Society Symposium 16:285-295.

Nobre CA, Marengo JA, Seluchi ME, Cuartas LA, Alves LM. 2016. Some characteristics and impacts of the drought and water crisis in Southeastern Brazil during 2014 and 2015. Journal of Water Resource and Protection 8:252-262 DOI 10.4236/jwarp.2016.82022.

Nogueira MG. 2001. Zooplankton composition, dominance and abundance as indicators of environmental compartmentalization in Jurumirim Reservoir (Paranapanema River), São Paulo, Brazil. Hydrobiologia 455:1-18 DOI 10.1023/A:1011946708757. 
755

756

757

758

759

760

761

762

763

764

765

766

767

768

769

770

771

772

773

774

775

776

777

778

779

780

781

782

783

784

785

786

787

788

789

790

791

792

793

Nogueira MG, Oliveira PCR, Britto YT. 2008. Zooplankton assemblages (Copepoda and Cladocera) in a cascade of reservoirs of a large tropical river (SE Brazil). Limnetica 27:151170 DOI 10.23818/limn.27.13.

Nogueira M, Perbiche-Neves G, Naliato DAO. 2012. Limnology of two contrasting hydroelectric reservoirs (storage and run-of-river) in southeast Brazil. In: Samadi-Boroujeni H, ed. Hydropower-practice and application. Rijeka: Intech, 167-184.

Oksanen J, Blanchet FG, Friendly M, Kindt R, Legendre P, McGlinn D, Minchin PR, O'Hara RB, Simpson GL, Solymos P, Stevens MHH, Szoecs E, Wagner H. 2016. Vegan: Community Ecology Package, R package version 2.0-6. Available at http://vegan.rforge.r-project.org (accessed 25 may 2019).

Okuku EO, Tole M, Kiteresi LI, Bouillon S. 2016. The response of phytoplankton and zooplankton to river damming in three cascading reservoirs of the Tana River, Kenya. Lakes \& Reservoirs: Research and Management 21:114-132 DOI 10.1111/1re.12127.

Oliveira AG, Baumgartner MT, Gomes LC, Dias RM, Agostinho AA. 2018. Long-term effects of flow regulation by dams simplify fish functional diversity. Freshwater Biology 63:293-305 DOI 10.1111/fwb.13064.

O'Reilly CM, Alin SR, Plisnier PD, Cohen AS, McKee BA. 2003. Climate change decreases aquatic ecosystem productivity of Lake Tanganyika, Africa. Nature 424:766-768 DOI 10.1038/nature01833.

Padisák J, Köhler J, Hoeg H. 1999. The effect of changing flushing rates on development of late summer Aphanizomenon and Microcystis populations in a shallow lake, Müggelsee, Berlin, Germany. In: Tundisi JG, Straškraba M, eds. Theoretical reservoir ecology and its applications. São Carlos: Backhuys Publishers, 411-423.

Paerl HW, Paul VJ. 2012. Climate change: links to global expansion of harmful cyanobacteria. Water Research 46:1349-1363 DOI 10.1016/j.watres.2011.08.002.

Perbiche-Neves G, Nogueira MG. 2010. Multi-dimensional effects on Cladoceran (Crustacea, Anomopoda) assemblages in two cascade reservoirs in Southeast Brazil. Lakes \& Reservoirs: Research and Management 15:139-152 DOI 10.1111/j.14401770.2010.00429.x.

Perbiche-Neves G, Nogueira MG. 2013. Reservoir design and operation: effects on aquatic biota-a case study of planktonic copepods. Hydrobiologia 707:187-198 DOI 10.1007/s10750-012-1425-1.

Perbiche-Neves G, Saito VS, Previatelli D, Rocha CEF, Nogueira MG. 2016. Cyclopoid copepods as bioindicators of eutrophication in reservoirs: do patterns hold for large spatial extents? Ecological Indicators 70:340-347 DOI 10.1016/j.ecolind.2016.06.028.

Perbiche-Neves G, Saito VS, Simões NR, Debastiani-Jr JR, Naliato DAO, Nogueira MG. 2019. Distinct responses of Copepoda and Cladocera diversity to climatic, environmental, and geographic filters in the La Plata River basin. Hydrobiologia 826:113-127 DOI 10.1007/s10750-018-3722-9. 
794

795

796

797

798

799

800

801

802

803

804

805

806

807

808

809

810

811

812

813

814

815

816

817

818

819

820

821

822

823

824

825

826

827

828

829

830

831

832

Pinto-Coelho RM, Pinel-Alloul B, Méthot G, Havens KE. 2005. Crustacean zooplankton in lakes and reservoirs of temperate and tropical regions: variation with trophic status. Canadian Journal of Fisheries and Aquatic Sciences 62:348-361 DOI 10.1139/f04-178.

Pinto-Coelho RM, Azevedo LM, Rizzi PEV, Bezerra-Neto JF, Rolla ME. 2006. Origens e efeitos do aporte externo de nutrientes em um reservatório tropical de grande porte: Reservatório de São Simão (MG/GO). In: Nogueira MG, Henry R, Jorcin A, eds. Ecologia de reservatórios: impactos potenciais, ações de manejo e sistemas em cascata. São Carlos: RiMa, 127-164.

R Core Team. 2015. R: a language and environment for statistical computing. Available at http://www.R-project.org (accessed 25 may 2019).

Ravazzani G, Gianoli P, Meucci S, Mancini M. 2014. Assessing downstream impacts of detention basins in urbanized river basins using a distributed hydrological model. Water Resources Management 28:1033-1044 DOI 10.1007/s11269-014-0532-3.

Reid JW. 1985. Key to the identification and a reference list for the continental South American species of free-living Cyclopoida (Crustacea, Copepoda). Boletim de Zoologia 9:17-143.

Rocha MIA, Recknagel F, Minoti RT, Huszar VLM, Kozlowsky-Suzuki B, Cao H, Starling FLRM, Branco CWC. 2019. Assessing the effect of abiotic variables and zooplankton on picocyanobacterial dominance in two tropical mesotrophic reservoirs by means of evolutionary computation. Water Research 149:120-129 DOI 10.1016/j.watres.2018.10.067.

Sampaio EV, Rocha O, Matsumura-Tundisi T, Tundisi JG. 2002. Composition and abundance of zooplankton in the limnetic zone of seven reservoir of Paranapanema River, Brazil. Brazilian Journal of Biology 62:525-545 DOI 10.1590/S1519-69842002000300018.

Sartori LP, Nogueira MG, Henry R, Moretto EM. 2009. Zooplankton fluctuations in Jurumirim Reservoir (São Paulo, Brazil): a three-year study. Brazilian Journal of Biology 69:1-18 DOI 10.1590/S1519-69842009000100002.

Segers, H. 2008. Global diversity of rotifers (Rotifera) in freshwater. Hydrobiologia 595:49-59 DOI 10.1007/s10750-007-9003-7.

Sema-Secretaria do Meio Ambiente. 2010. Bacias hidrográficas do Paraná. Curitiba: SEMA.

Sendacz S, Caleffi S, Santos-Soares J. 2006. Zooplankton biomass of reservoirs in different trophic conditions in the state of São Paulo, Brazil. Brazilian Journal of Biology 66:337-350 DOI 10.1590/S1519-69842006000200016.

Serafim-Jr. M, Lansac-Tôha FA, Lopes RM, Perbiche-Neves G. 2016. Continuity effects on rotifers and microcrustaceans caused by the construction of a downstream reservoir in a cascade series (Iguaçu River, Brazil). Brazilian Journal of Biology 76:279-291 DOI 10.1590/1519-6984.00314.

Silva LHS, Huszar VLM, Marinho MM, Rangel LM, Brasil J, Domingues CD, Branco CC, Roland F. 2014. Drivers of phytoplankton, bacterioplankton, and zooplankton carbon biomass in tropical hydroelectric reservoirs. Limnologica 48:1-10 DOI 10.1016/j.limno.2014.04.004. 
833 Sluss TD, Cobbs GA, Thorp JH. 2008. Impact of turbulence on riverine zooplankton: a

834

835

836

837

838

839

840

841

842

843

844

845

846

847

848

849

850

851

852

853

854

855

856

857

858

859

860

861

862

863

864

865

866

867

868

869

870 mesocosm experiment. Freshwater Biology 53:1999-2010 DOI 10.1111/j.13652427.2008.02023.x.

Soares MCS, Marinho MM, Azevedo SMOF, Branco CWC, Huszar VLM. 2012. Eutrophication and retention time affecting spatial heterogeneity in a tropical reservoir. Limnologica 42:197-203 DOI 10.1016/j.limno.2011.11.002.

Sokal RR, Rohlf FJ. 1991. Biometry: the principles and practice of statistics in biological research. New York: Freeman.

Su M, Andersen T, Burch M, Jia Z, An W, Yu J, Yang N. 2019. Succession and interaction of surface and subsurface cyanobacterial blooms in oligotrophic/mesotrophic reservoirs: a case study in Miyun Reservoir. Science of the Total Environment 649:1553-1562 DOI 10.1016/j.scitotenv.2018.08.307.

Tang J, Cao H. 2018. Structural adaptions of phytoplankton assemblages along two contrasting reservoirs. Biologia 74:139-148 DOI 10.2478/s11756-018-0160-0.

Ter-Braak CJF, Verdonschot PFM. 1995. Canonical correspondence analysis and related multivariate methods in aquatic ecology. Aquatic Science 57:255-289 DOI 10.1007/BF00877430.

Thatcher SJ, Davis CC, Gardner GA. 1993. Physical and chemical effects of macrograzers and micrograzers on enclosed, in situ phytoplankton in a Newfoundland Lake. Hydrobiologia 250:127-141 DOI 10.1007/BF00008234.

Thornton KE, Kimmel BL, Payne FE. 1990. Reservoir Limnology: ecological perpectives. New York: John Wiley and Sons.

Tundisi JG, Matsumura-Tundisi T, Abe DS. 2008. The ecological dynamics of Barra Bonita (Tietê River, SP, Brazil) reservoir: implications for its biodiversity. Brazilian Journal of Biology 68:1079-1098 DOI 10.1590/S1519-69842008000500015.

Velho LFM, Lansac-Tôha FA, Bonecker CC. 2005. Distribuição longitudinal da comunidade zooplanctônica em reservatórios. In: Rodrigues L, Thomaz SM, Agostinho AA, Gomes LC, eds. Biocenoses em reservatórios: padrões espaciais e temporais. São Carlos: RiMa, 129136.

Verburg P, Hecky RE, King H. 2003. Ecological consequences of a century of warming in Lake Tanganyika. Science 301:505-507 DOI 10.1126/science.1084846.

Vinebrooke RD, Cottingham KL, Norberg J, Scheffer M, Dodson SI, Maberly SC, Sommer U. 2004. Impacts of multiple stressors on biodiversity and ecosystem functioning: the role of species co-tolerance. Oikos 104:451-457 DOI 10.1111/j.0030-1299.2004.13255.x.

Viroux L. 2002. Seasonal and longitudinal aspects of microcrustacean (Cladocera, Copepoda) dynamics in a lowland river. Journal of Plankton Research 24:281-292 DOI 10.1093/plankt/24.4.281.

Wetzel RG, Likens GE. 2000. Limnological analyses. New York: Springer-Verlag. 
Figure 1

Map of the Salto Santiago and Salto Osório reservoirs, and the sampling sites in the Iguaçu River, Brazil.

Environments: fluvial (S1 and S5), transitional (S2 and S6), lacustrine (S3 and S7), and downstream (S4 and S8).

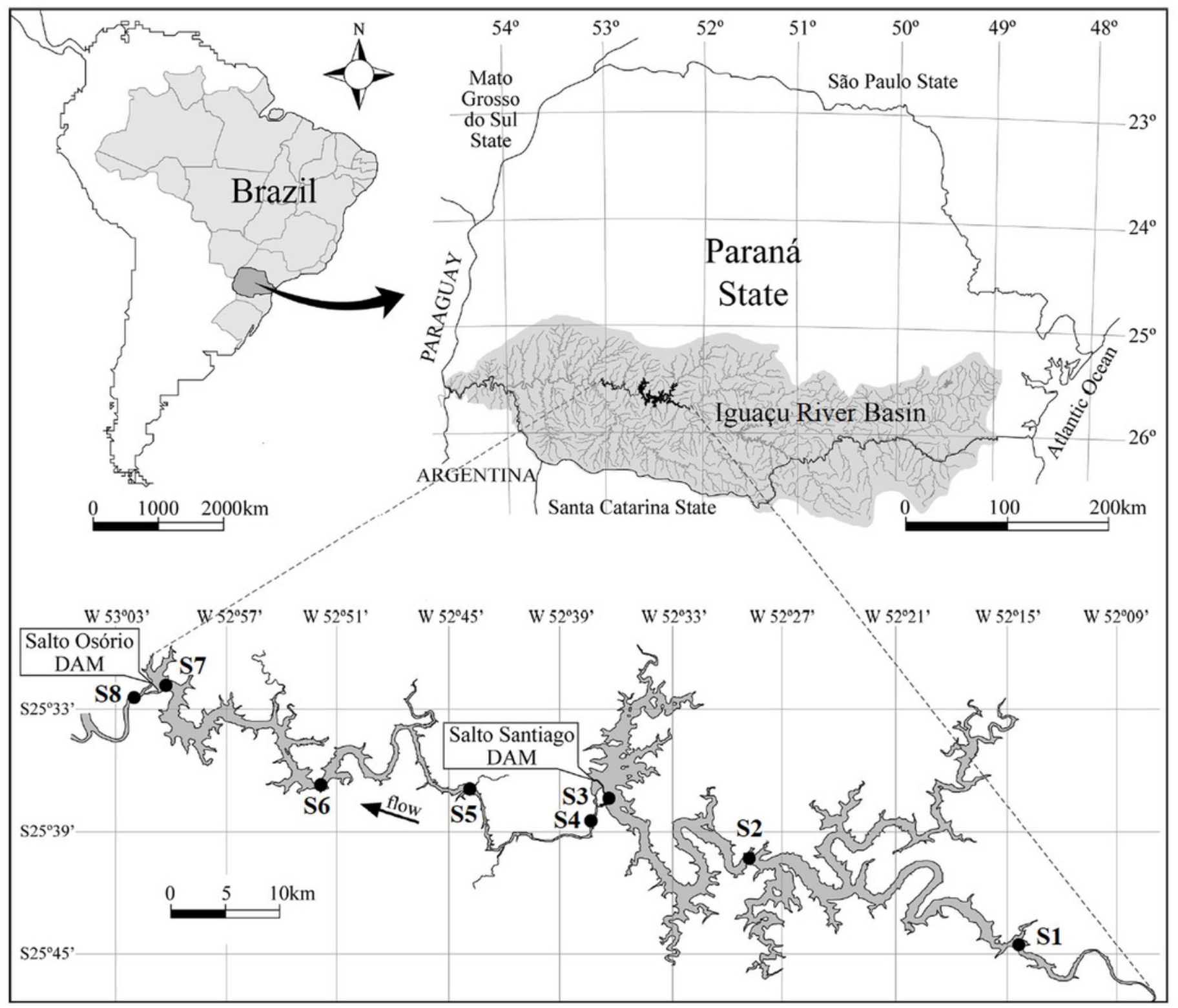


Figure 2

Variation in rainfall and water flow (WF) during the study period for the region.

Region comprised of the Salto Santiago and Salto Osório reservoirs, Iguaçu River, Brazil. Data are the total accumulated rainfall and mean water flow values in the reservoirs during the sampling months.

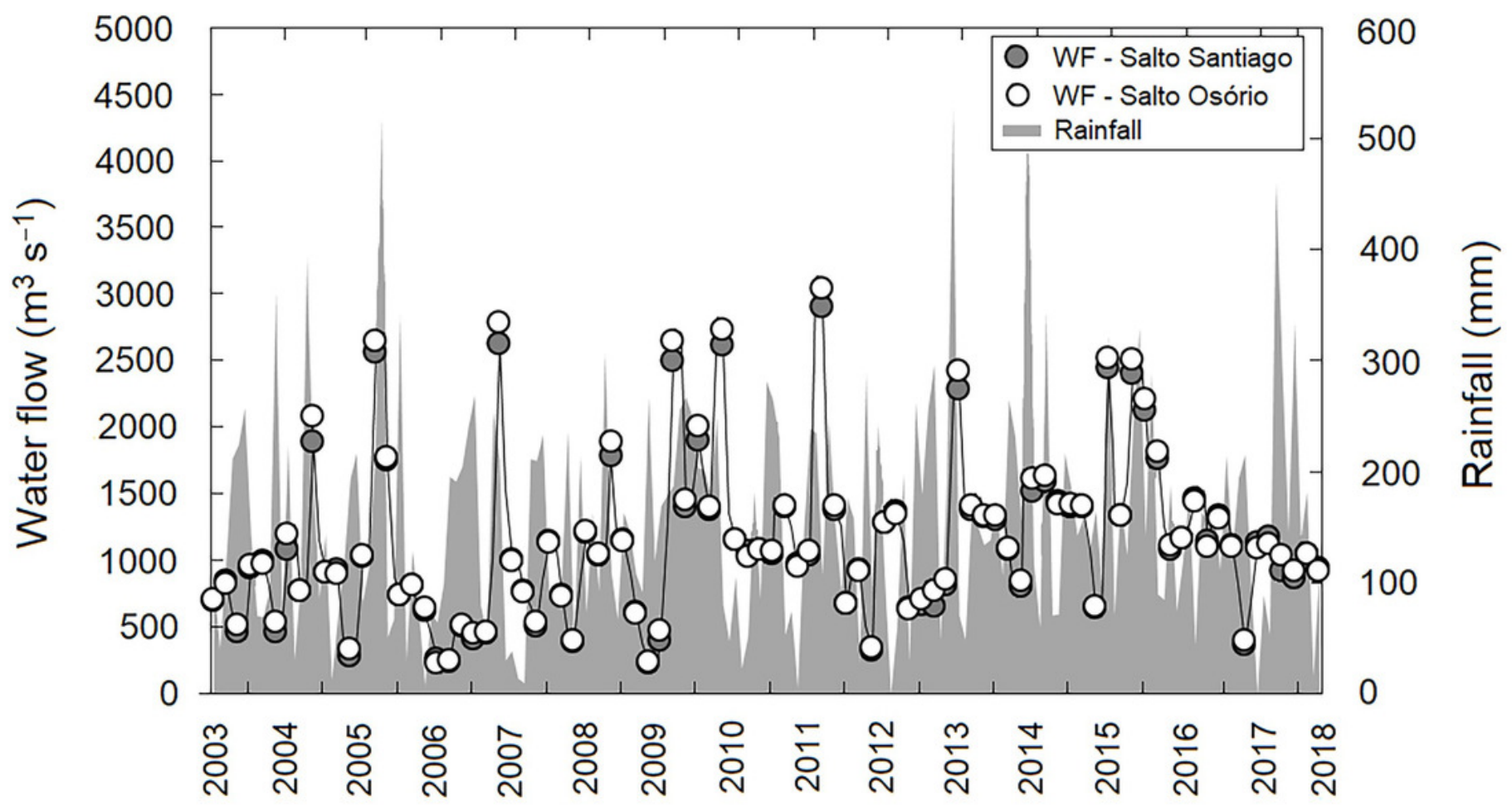


Figure 3

Trophic state indexes (TSIs).

Mean values of the TSIs calculated for the environments influenced by the (A) Salto Santiago and (B) Salto Osório reservoirs. Horizontal lines indicate the ranges for each trophic state: oligotrophic (O), mesotrophic (M), and eutrophic (E).

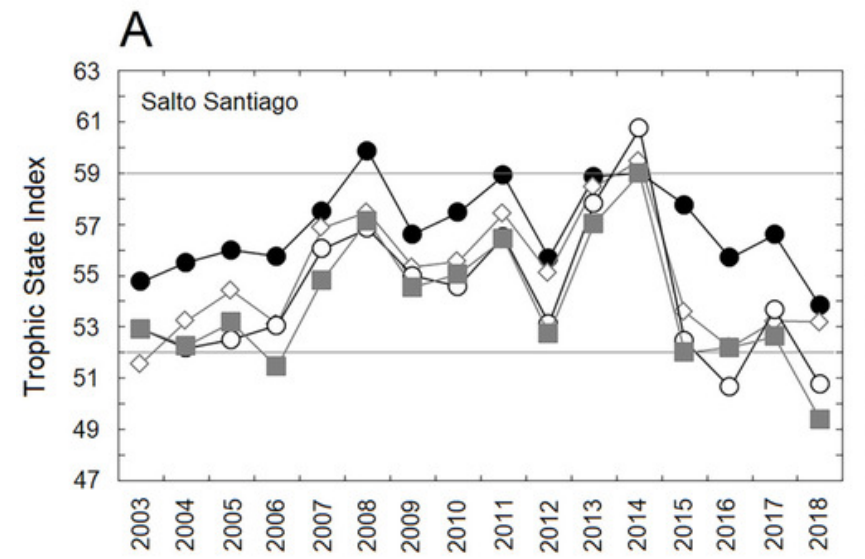

B

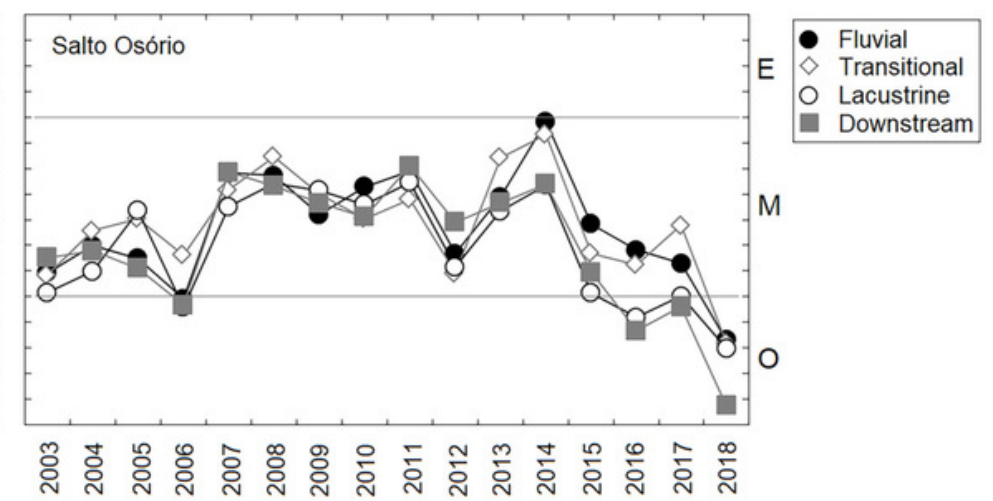


Figure 4

Inter-annual variations in the richness and abundance of zooplankton.

Data shows the mean ( $\pm \mathrm{SE}$ ) richness and abundance values for total zooplankton, rotifers, cladocerans, and copepods in the (A, B) Salto Santiago and (C, D) Salto Osório reservoirs.
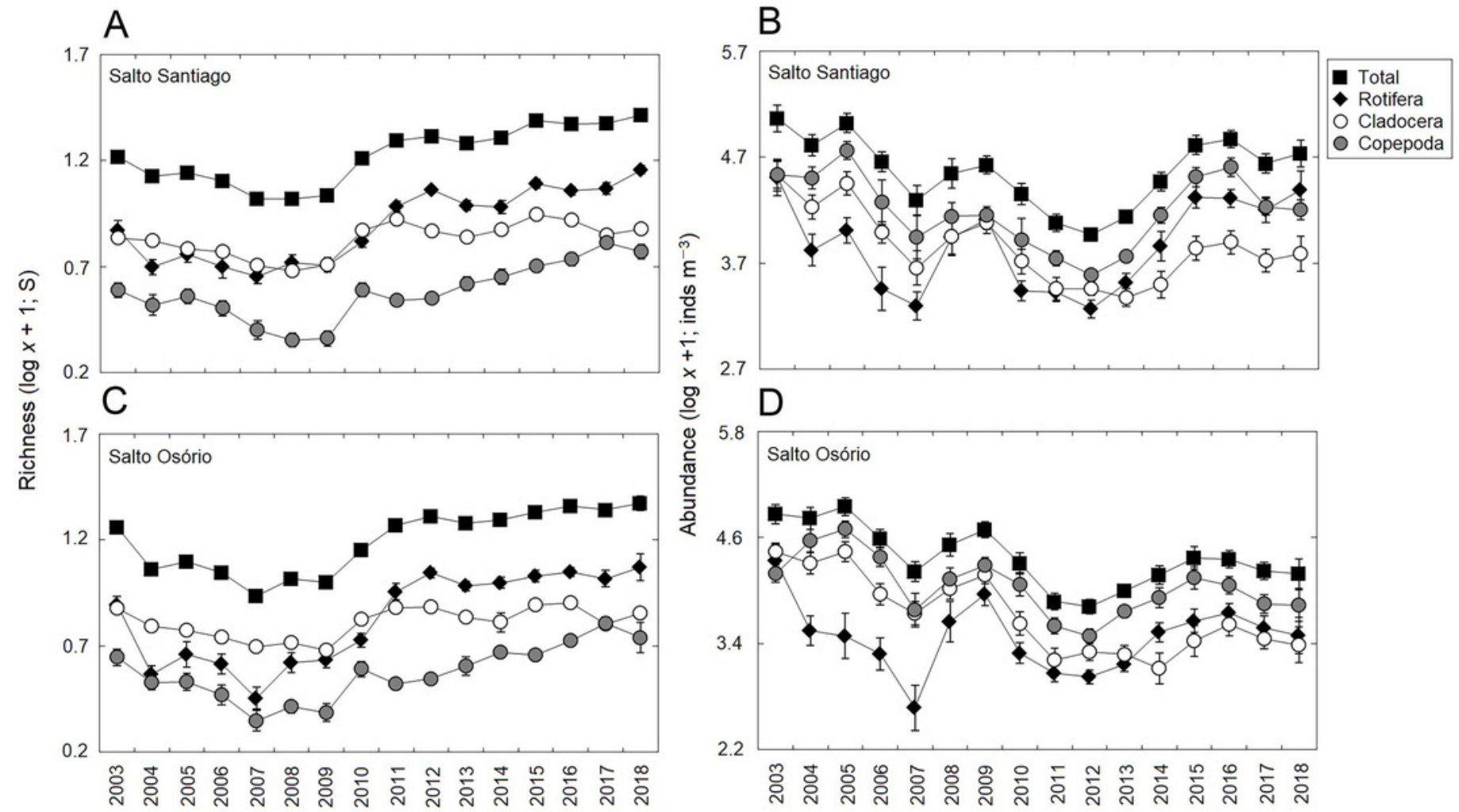
Figure 5

Seasonal variations in zooplankton richness and abundance.

Data shows the mean $( \pm S E)$ richness and abundance of total zooplankton, rotifers, cladocerans, and copepods in the (A, B) Salto Santiago and (C, D) Salto Osório reservoirs.
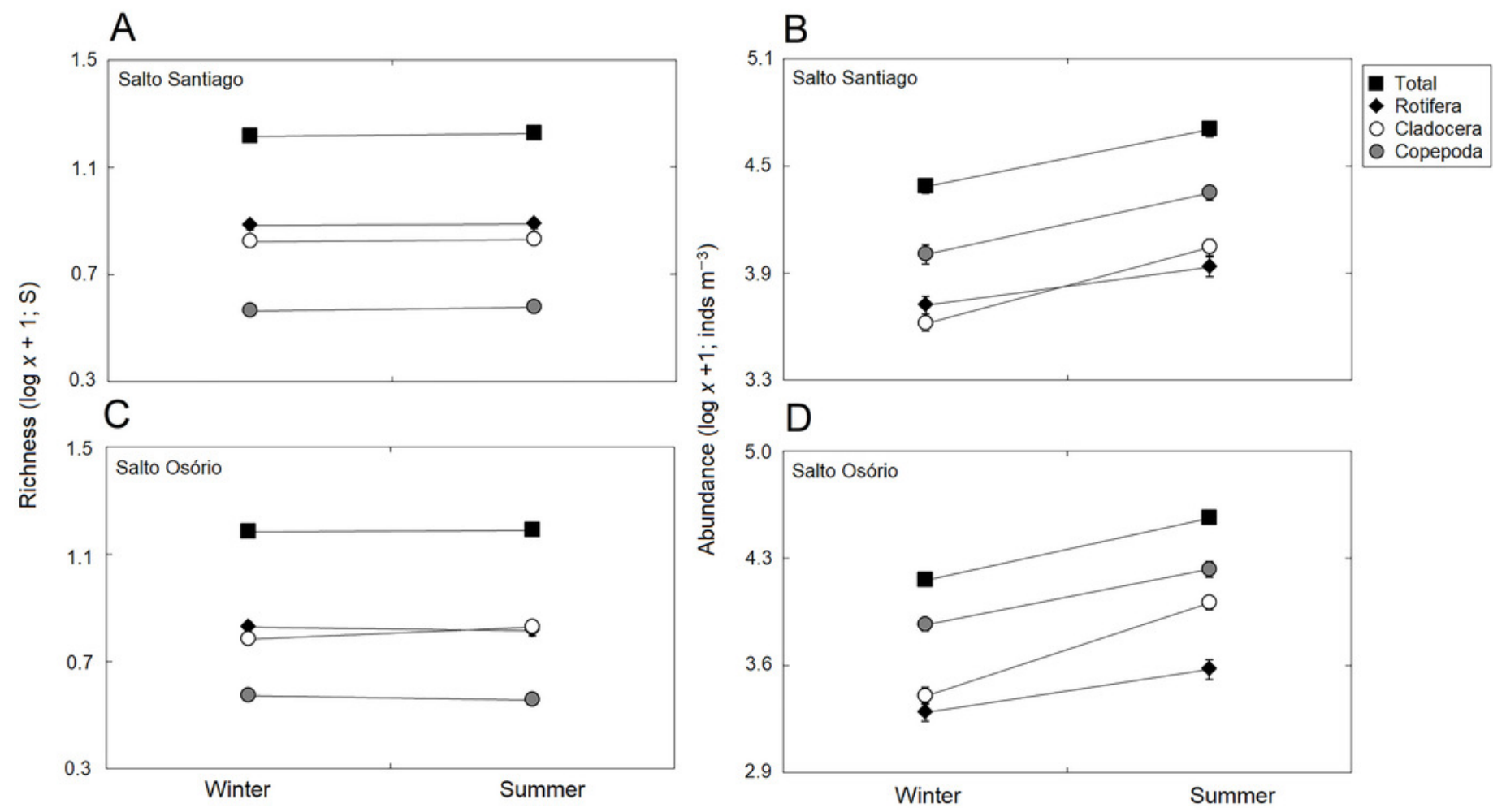
Figure 6

Spatial variations in the richness and abundance of zooplankton.

Data shows the mean ( $\pm \mathrm{SE}$ ) richness and abundances of the total zooplankton, rotifers, cladocerans, and copepods in the (A, B) Salto Santiago and (C, D) Salto Osório reservoirs.
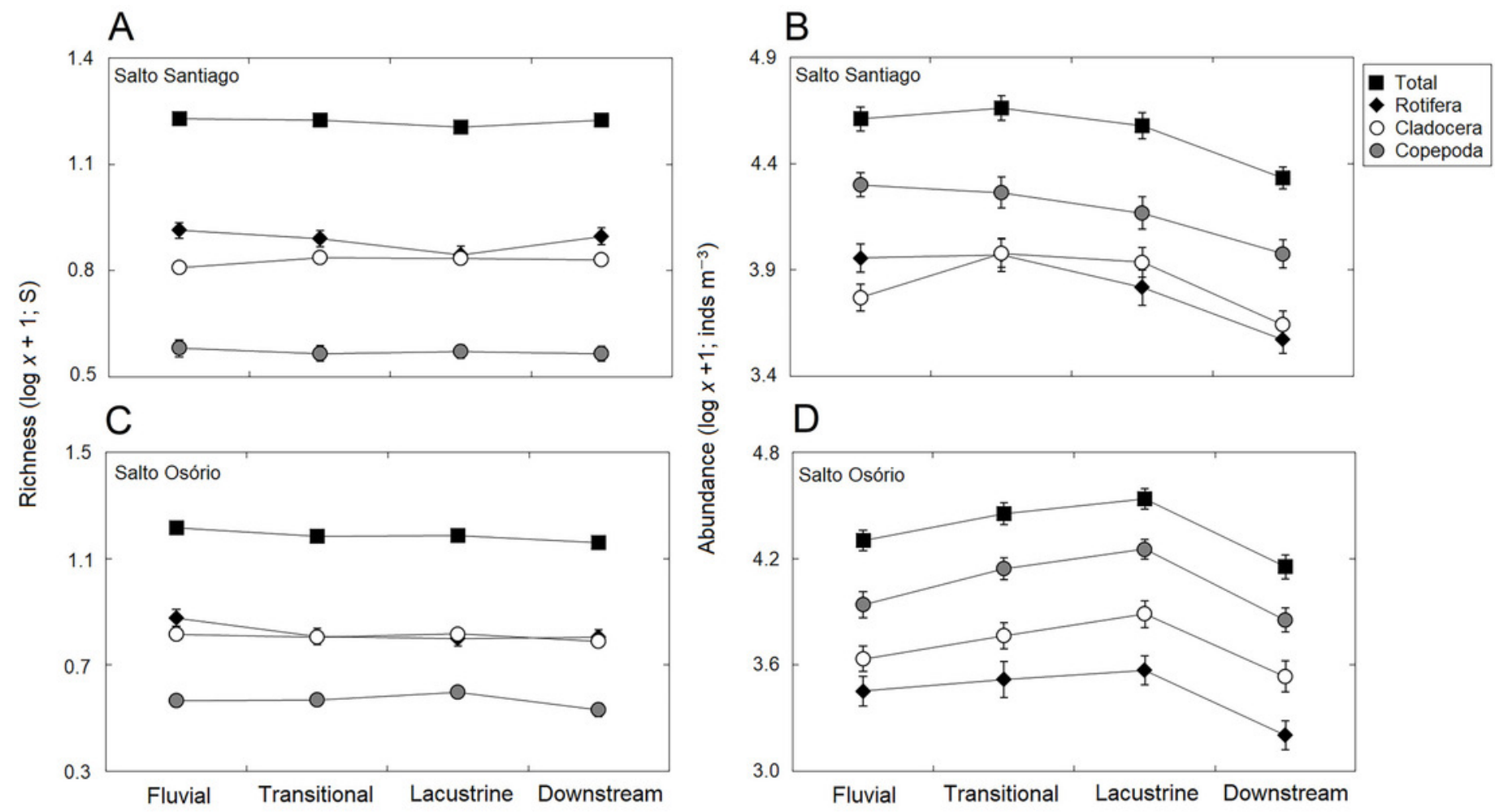
Figure 7

Ordination diagrams for the non-metric multidimensional scaling (NMDS) analysis.

Positions respective to the sampling year, period, and environment were used as symbol factors for the zooplankton communities in the (A, C, E) Salto Santiago and (B, D, F) Salto Osório reservoirs.

A

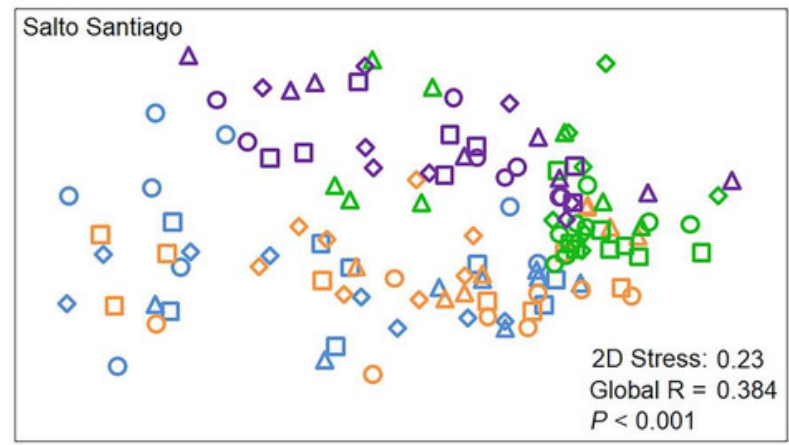

\section{C}

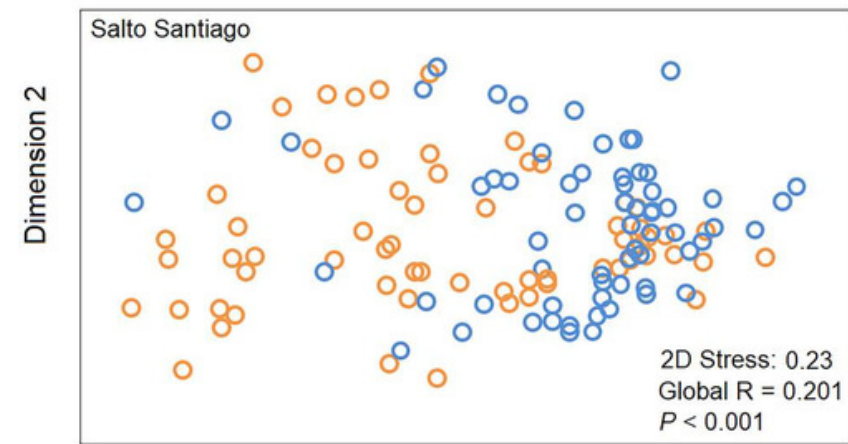

E

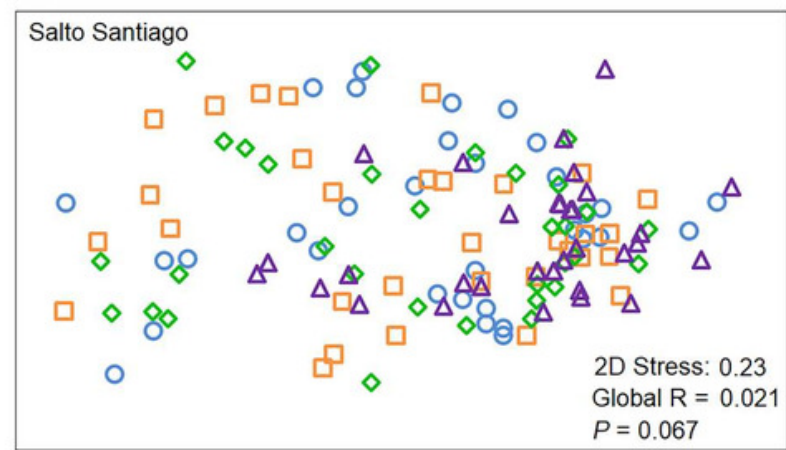

B

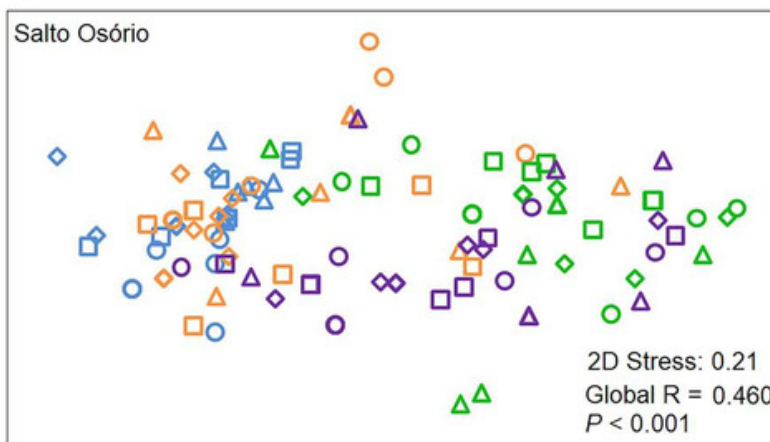

○ $2003 \circ 2011$

$\square 2004 \square 2012$

$\diamond 2005 \diamond 2013$

$\triangle 2006 \triangle 2014$

○ 2007 ○ 2015

$\square 2008 \square 2016$

$\diamond 2009 \diamond 2017$

$\triangle 2010 \triangle 2018$

D

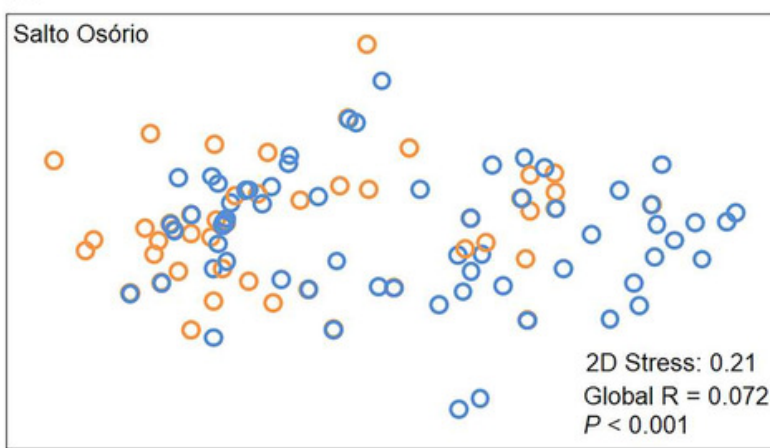

F

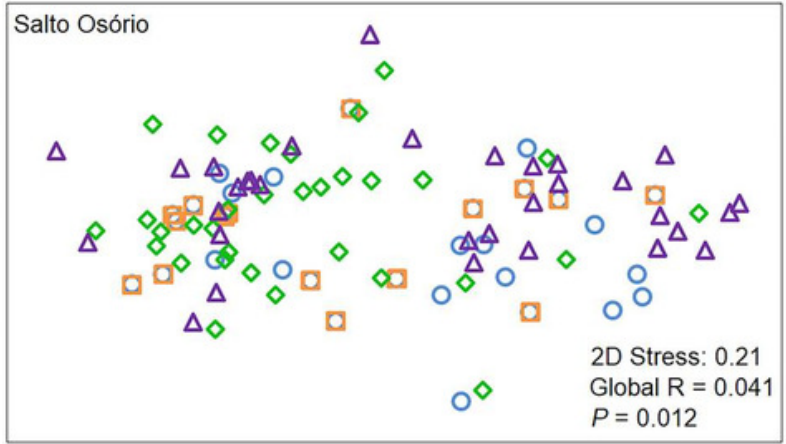

O Fluvial

$\square$ Transitional $\diamond$ Lacustrine

$\triangle$ Downstream

Dimension 1 


\section{Figure 8}

Zooplankton relative abundances for each year and season.

Percentage contribution of zooplankton species in the mean total abundance of zooplankton in the $(A, B)$ Salto Santiago and $(C, D)$ Salto Osório reservoirs. Only the species that the SIMPER test had shown contributed the most to community temporal variation are shown.
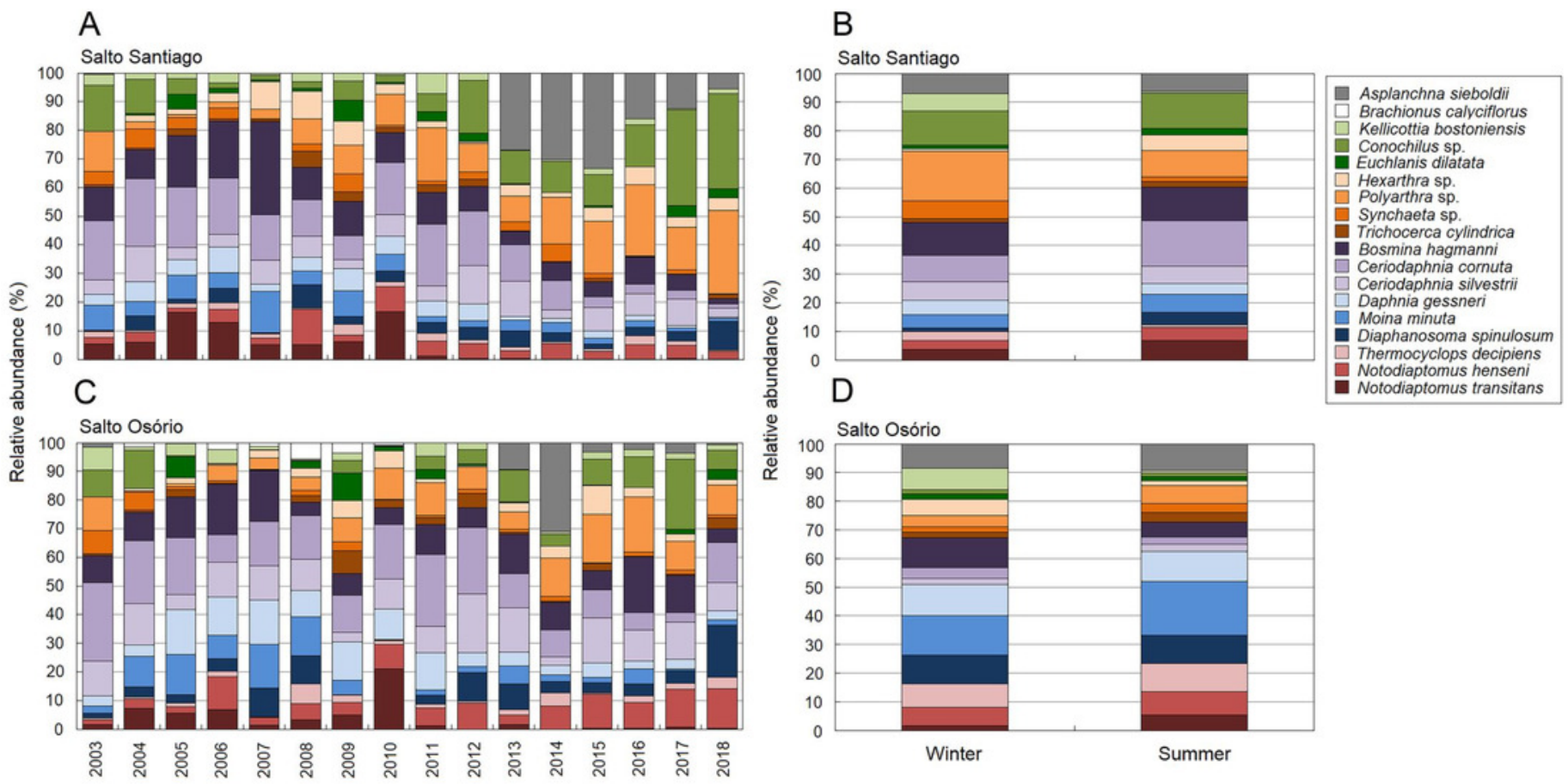


\section{Figure 9}

Canonical correspondence analysis (CCA).

The CCA shows the relationships among the environmental variables, zooplankton species, and the environments of the (A, C, E) Salto Santiago and (B, D, F) Salto Osório reservoirs. Open circles (winter), closed circles (summer), chlorophyll a (Chl a), dissolved oxygen (DO), maximum depth $\left(Z_{\max }\right)$, Secchi disk depth $\left(Z_{\text {sD }}\right)$, electrical conductivity (Cond), total dissolved solids (TDS), total nitrogen (TN), total phosphorus (TP), turbidity (Turb), water temperature (WT), and trophic state index (TSI). 

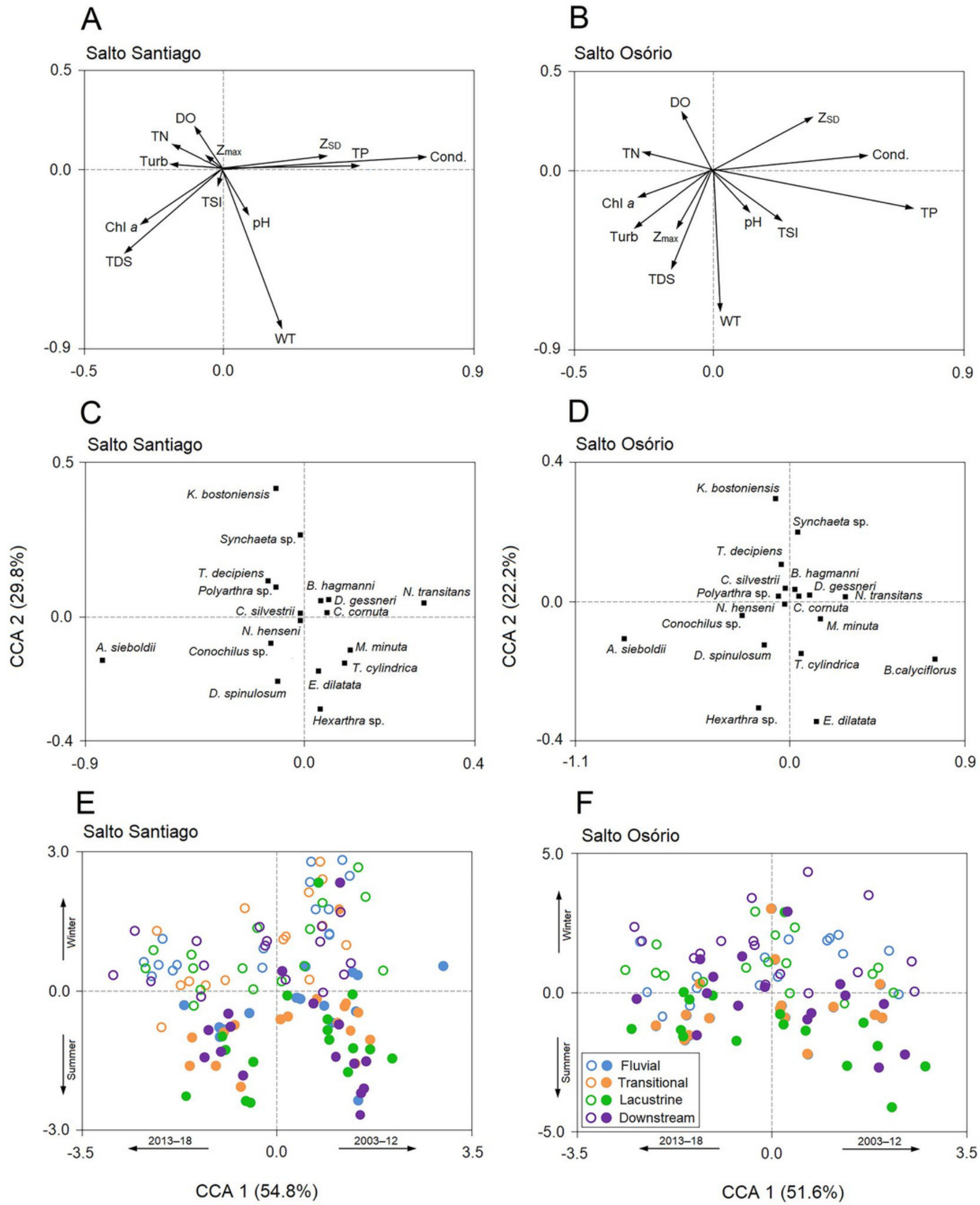


\section{Table $\mathbf{1}$ (on next page)}

Hydrological data.

Mean values, coefficients of variation (CV in \%) and ANOVA results for the parameters in each environment and for seasonality (winter and summer periods) in the study region.

Notes: Bold ANOVA results ( $P$ values) are significant $(P<0.05)$. Chlorophyll a $(\mathrm{Chl}$ a), dissolved oxygen (DO), maximum depth $\left(Z_{\max }\right)$, Secchi disk depth $\left(Z_{\mathrm{SD}}\right)$, electrical conductivity (Cond), total dissolved solids (TDS), total nitrogen (TN), total phosphorus (TP), turbidity (Turb), water temperature (WT), and trophic state index (TSI). 


\section{Table 1}

\begin{tabular}{lrrrrrrrrrrrr}
\hline & Chl- $a$ & DO & $Z_{\max }$ & $Z_{\mathrm{SD}}$ & Cond & pH & TDS & TN & TP & Turb & WT & TSI \\
\hline S1 & 1.6 & 7.3 & 38.2 & 1.6 & 42.6 & 6.9 & 5.5 & 0.67 & 0.09 & 9.0 & 21.7 & 57.0 \\
& $121 \%$ & $21 \%$ & $18 \%$ & $33 \%$ & $26 \%$ & $11 \%$ & $469 \%$ & $131 \%$ & $96 \%$ & $64 \%$ & $15 \%$ & $5 \%$ \\
S2 & 2.2 & 7.7 & 62.1 & 2.3 & 42.3 & 7.2 & 2.9 & 0.61 & 0.08 & 6.1 & 22.9 & 55.2 \\
& $176 \%$ & $19 \%$ & $19 \%$ & $35 \%$ & $27 \%$ & $12 \%$ & $141 \%$ & $140 \%$ & $106 \%$ & $97 \%$ & $17 \%$ & $7 \%$ \\
S3 & 2.4 & 7.6 & 64.9 & 2.6 & 42.4 & 7.1 & 4.4 & 0.59 & 0.08 & 7.4 & 23.3 & 54.5 \\
& $254 \%$ & $16 \%$ & $13 \%$ & $35 \%$ & $26 \%$ & $11 \%$ & $267 \%$ & $115 \%$ & $105 \%$ & $312 \%$ & $15 \%$ & $8 \%$ \\
S4 & 1.3 & 7.3 & 7.9 & 2.5 & 41.6 & 6.9 & 6.0 & 0.64 & 0.08 & 5.9 & 21.1 & 54.1 \\
& $166 \%$ & $23 \%$ & $6 \%$ & $36 \%$ & $29 \%$ & $8 \%$ & $375 \%$ & $123 \%$ & $107 \%$ & $105 \%$ & $13 \%$ & $6 \%$ \\
S5 & 1.2 & 7.4 & 33.1 & 2.3 & 43.1 & 7.0 & 4.5 & 0.64 & 0.08 & 7.9 & 21.1 & 54.9 \\
& $101 \%$ & $23 \%$ & $17 \%$ & $37 \%$ & $27 \%$ & $8 \%$ & $359 \%$ & $122 \%$ & $100 \%$ & $165 \%$ & $14 \%$ & $6 \%$ \\
S6 & 1.4 & 7.6 & 34.2 & 2.3 & 43.0 & 7.0 & 2.6 & 0.54 & 0.08 & 7.1 & 22.4 & 55.0 \\
& $120 \%$ & $23 \%$ & $19 \%$ & $38 \%$ & $30 \%$ & $9 \%$ & $120 \%$ & $120 \%$ & $100 \%$ & $119 \%$ & $15 \%$ & $6 \%$ \\
S7 & 1.4 & 7.7 & 42.0 & 2.6 & 43.1 & 7.1 & 3.2 & 0.61 & 0.08 & 5.8 & 23.2 & 54.1 \\
& $143 \%$ & $19 \%$ & $9 \%$ & $34 \%$ & $27 \%$ & $11 \%$ & $162 \%$ & $108 \%$ & $105 \%$ & $130 \%$ & $15 \%$ & $6 \%$ \\
S8 & 1.3 & 7.0 & 5.9 & 2.5 & 41.5 & 5.9 & 2.4 & 0.59 & 0.08 & 6.2 & 21.4 & 54.2 \\
& $218 \%$ & $23 \%$ & $7 \%$ & $39 \%$ & $28 \%$ & $7 \%$ & $130 \%$ & $116 \%$ & $101 \%$ & $99 \%$ & $13 \%$ & $6 \%$ \\
Winter & 1.4 & 7.8 & 36.2 & 2.4 & 42.7 & 7.0 & 3.0 & 0.62 & 0.08 & 8.0 & 19.6 & 55.0 \\
& $142 \%$ & $20 \%$ & $59 \%$ & $41 \%$ & $32 \%$ & $10 \%$ & $133 \%$ & $107 \%$ & $99 \%$ & $185 \%$ & $10 \%$ & $6 \%$ \\
Summer & 1.8 & 7.1 & 35.9 & 2.3 & 42.2 & 7.0 & 4.9 & 0.61 & 0.07 & 5.8 & 24.6 & 54.7 \\
& $217 \%$ & $20 \%$ & $59 \%$ & $36 \%$ & $21 \%$ & $10 \%$ & $402 \%$ & $136 \%$ & $105 \%$ & $76 \%$ & $10 \%$ & $7 \%$ \\
$P$ values & & & & & & & & & & & & \\
Year & $<\mathbf{0 . 0 0 1}$ & $<\mathbf{0 . 0 0 1}$ & $<\mathbf{0 . 0 0 1}$ & $<\mathbf{0 . 0 0 1}$ & $<\mathbf{0 . 0 0 1}$ & $<\mathbf{0 . 0 0 1}$ & $<\mathbf{0 . 0 0 1}$ & $<\mathbf{0 . 0 0 1}$ & $<\mathbf{0 . 0 0 1}$ & $<\mathbf{0 . 0 0 1}$ & $\mathbf{0 . 0 1 2}$ & $<\mathbf{0 . 0 0 1}$ \\
Period & 0.559 & $<\mathbf{0 . 0 0 1}$ & 0.363 & 0.473 & 0.526 & 0.221 & 0.623 & 0.149 & $\mathbf{0 . 0 2 7}$ & 0.279 & $<\mathbf{0 . 0 0 1}$ & 0.131 \\
Reservoir & $\mathbf{0 . 0 2 6}$ & 0.406 & $<\mathbf{0 . 0 0 1}$ & $\mathbf{0 . 0 0 1}$ & 0.544 & 0.757 & 0.171 & 0.716 & 0.656 & 0.368 & 0.225 & $\mathbf{0 . 0 0 3}$ \\
Environmen & $\mathbf{0 . 0 4 7}$ & $\mathbf{0 . 0 0 1}$ & $<\mathbf{0 . 0 0 1}$ & $<\mathbf{0 . 0 0 1}$ & 0.394 & $\mathbf{0 . 0 0 8}$ & 0.461 & 0.609 & 0.914 & $<\mathbf{0 . 0 0 1}$ & $<\mathbf{0 . 0 0 1}$ & $<\mathbf{0 . 0 0 1}$ \\
\hline & & & & & & & & & & &
\end{tabular}




\section{Table 2 (on next page)}

Taxonomic composition, frequency of occurrence (\%) and mean abundance (in parentheses) of each zooplankton taxa in each environment influenced by the Salto Santiago and Salto Osório reservoirs.

Notes: Environments: fluvial (S1 and S5), transitional (S2 and S6), lacustrine (S3 and S7), and downstream (S4 and S8). Rare species ( $\leq 10 \%)$ in the study are not included in the table. 


\section{Table 2}

\begin{tabular}{|c|c|c|c|c|c|c|c|c|}
\hline Taxa & $\mathrm{S} 1$ & S2 & $\mathrm{S} 3$ & S4 & S5 & S6 & S7 & S8 \\
\hline \multicolumn{9}{|l|}{ Rotifera } \\
\hline Ascomorpha sp. & $22(246)$ & $17(64)$ & $11(11)$ & $20(35)$ & $17(24)$ & $20(228)$ & $14(77)$ & $16(14)$ \\
\hline Asplanchna sieboldii & $34(3,313)$ & $38(5,258)$ & $32(1,943)$ & $31(615)$ & $29(141)$ & $30(293)$ & $31(1,211)$ & $27(81)$ \\
\hline Brachionus calyciflorus & $18(404)$ & $11(309)$ & $12(427)$ & $11(337)$ & $17(101)$ & $14(851)$ & $12(602)$ & $18(1,070)$ \\
\hline Brachionus dolabratus & $9(14)$ & $11(82)$ & $16(138)$ & $19(26)$ & $14(29)$ & $10(19)$ & $12(44)$ & $9(21)$ \\
\hline Brachionus falcatus & $14(101)$ & $17(34)$ & $19(121)$ & $18(32)$ & $21(27)$ & $19(50)$ & $16(47)$ & $14(39)$ \\
\hline Collotheca sp. & $9(17)$ & $9(18)$ & $12(46)$ & $10(14)$ & $13(28)$ & $9(17)$ & $10(172)$ & $10(3)$ \\
\hline Conochilus sp. & $64(3,570)$ & $67(6,448)$ & $67(6,598)$ & $66(1,918)$ & $58(807)$ & $61(3,129)$ & $59(2,633)$ & $51(1,210)$ \\
\hline Euchlanis dilatata & $31(881)$ & $46(961)$ & $39(677)$ & $48(1,045)$ & $40(855)$ & $27(793)$ & $22(671)$ & $14(464)$ \\
\hline Filinia opoliensis & $24(707)$ & $24(191)$ & $12(88)$ & $20(56)$ & $18(89)$ & $11(41)$ & $11(32)$ & $10(411)$ \\
\hline Hexarthra sp. & $57(1,864)$ & $62(1,462)$ & $60(3,002)$ & $57(639)$ & $56(794)$ & $49(420)$ & 48 (798) & $28(379)$ \\
\hline Kellicottia bostoniensis & $67(1,204)$ & $50(1,097)$ & $49(614)$ & $62(713)$ & $67(779)$ & $57(958)$ & $38(477)$ & $56(1,134)$ \\
\hline Keratella americana & $33(107)$ & $31(69)$ & $33(66)$ & $34(42)$ & $31(35)$ & $31(79)$ & $23(29)$ & $27(21)$ \\
\hline Keratella cochlearis & $51(1,717)$ & $51(587)$ & $44(176)$ & $46(132)$ & $51(215)$ & $39(280)$ & 44 (177) & $38(59)$ \\
\hline Keratella tropica & $39(596)$ & $27(311)$ & $24(136)$ & $19(109)$ & $31(470)$ & $23(488)$ & $19(215)$ & $14(127)$ \\
\hline Ploesoma truncatum & $36(377)$ & $21(673)$ & $17(94)$ & $47(184)$ & $42(148)$ & $23(52)$ & $20(127)$ & $36(140)$ \\
\hline Polyarthra sp. & $82(5,232)$ & $82(5,859)$ & $70(4,870)$ & $82(1,992)$ & $74(2,444)$ & $76(3,583)$ & $79(2,002)$ & $77(1,042)$ \\
\hline Ptygura sp. & $11(82)$ & $10(11)$ & $14(245)$ & $16(44)$ & $14(35)$ & $11(7)$ & $10(11)$ & $14(44)$ \\
\hline Synchaeta sp. & $57(1,925)$ & $52(1,920)$ & $44(1,080)$ & $34(341)$ & $50(751)$ & $44(798)$ & $42(578)$ & $36(739)$ \\
\hline Trichocerca cylindrica & $36(441)$ & $44(1,031)$ & $41(708)$ & $54(703)$ & $50(594)$ & $31(316)$ & 49 (698) & $44(470)$ \\
\hline Trichocerca similis & $14(51)$ & $7(62)$ & $8(11)$ & $10(14)$ & $12(18)$ & $7(35)$ & $7(8)$ & $12(9)$ \\
\hline \multicolumn{9}{|l|}{ Cladocera } \\
\hline Bosmina freyi & $20(95)$ & $19(303)$ & $21(205)$ & $20(125)$ & $21(104)$ & $21(279)$ & 18 (189) & $19(52)$ \\
\hline Bosmina hagmanni & $90(3,703)$ & $98(5,608)$ & $98(7,256)$ & $94(2,480)$ & $93(2,828)$ & $93(4,115)$ & $90(3,172)$ & $92(2,814)$ \\
\hline Bosminopsis deitersi & $56(876)$ & $38(422)$ & $29(116)$ & $24(82)$ & $37(118)$ & $29(376)$ & $20(61)$ & $21(85)$ \\
\hline Ceriodaphnia cornuta & $87(5,255)$ & $92(7,182)$ & $88(6,138)$ & $92(2,593)$ & $86(3,590)$ & $81(4,417)$ & $93(5,854)$ & $86(2,945)$ \\
\hline Ceriodaphnia silvestrii & $74(1,947)$ & $81(3,734)$ & $83(2,535)$ & $84(2,203)$ & $82(2,198)$ & $78(1,780)$ & $79(3,611)$ & $78(2,249)$ \\
\hline Daphnia gessneri & $76(1,609)$ & $87(2,498)$ & $83(1,980)$ & 87 (889) & $86(2,183)$ & $81(1,605)$ & $84(2,359)$ & $83(3,770)$ \\
\hline Diaphanosoma birgei & $12(47)$ & $19(216)$ & $21(208)$ & $17(41)$ & $9(110)$ & $21(86)$ & $20(213)$ & $16(41)$ \\
\hline Diaphanosoma spinulosum & $59(676)$ & $64(1,402)$ & $69(2,917)$ & $67(782)$ & $58(476)$ & $61(1,266)$ & $69(2,166)$ & $52(1,382)$ \\
\hline Moina minuta & $68(2,903)$ & $72(2,395)$ & $72(2,703)$ & $64(1,010)$ & $69(2,086)$ & $63(1,544)$ & $64(2,309)$ & $59(1,988)$ \\
\hline \multicolumn{9}{|l|}{ Copepoda } \\
\hline Nauplii Cyclopoida & $92(12,376)$ & $91(12,127)$ & $88(9,239)$ & $89(5,787)$ & $86(4,589)$ & $90(7,109)$ & $87(6,868)$ & $94(4,960)$ \\
\hline Nauplii Calanoida & $99(8,775)$ & $97(9,091)$ & $93(7,001)$ & $96(3,018)$ & $92(3,815)$ & $94(6,064)$ & $96(6,422)$ & $92(4,061)$ \\
\hline Copepodit Cyclopoida & $88(2,566)$ & $83(2,921)$ & $70(2,665)$ & $77(1,273)$ & $81(2,057)$ & $69(1,694)$ & $77(1,549)$ & $78(1,497)$ \\
\hline Copepodit Calanoida & $97(11,168)$ & $94(10,107)$ & $97(14,235)$ & $98(6,762)$ & $99(8,511)$ & $99(12,681)$ & $\begin{array}{r}100 \\
(15,509)\end{array}$ & $\begin{array}{r}100 \\
(11,281)\end{array}$ \\
\hline Acanthocyclops robustus & $18(22)$ & $12(14)$ & $12(13)$ & $14(9)$ & $17(13)$ & $13(13)$ & $10(29)$ & $12(4)$ \\
\hline Argyrodiaptomus furcatus & $17(81)$ & $13(62)$ & $14(47)$ & $10(18)$ & $12(28)$ & $14(76)$ & $10(45)$ & $12(21)$ \\
\hline Mesocyclops meridianus & $14(59)$ & $16(26)$ & $13(15)$ & $18(21)$ & $17(16)$ & $16(37)$ & $13(65)$ & $13(12)$ \\
\hline
\end{tabular}




\begin{tabular}{|c|c|c|c|c|c|c|c|c|}
\hline Notodiaptomus henseni & $78(1,630)$ & $80(2,320)$ & $79(2,086)$ & $82(923)$ & $79(926)$ & $80(2,525)$ & $87(2,969)$ & $76(1,051)$ \\
\hline Notodiaptomus iheringi & $21(123)$ & $18(122)$ & $14(125)$ & $14(63)$ & $16(66)$ & $16(101)$ & 27 (249) & $18(67)$ \\
\hline Notodiaptomus sp. & $7(32)$ & $11(17)$ & $11(14)$ & $7(9)$ & $9(29)$ & $13(45)$ & $13(69)$ & $11(15)$ \\
\hline Notodiaptomus transitans & $50(1,959)$ & $53(5,151)$ & $48(1,604)$ & $49(1,060)$ & $49(1,024)$ & $52(2,447)$ & $57(2,184)$ & $38(1,016)$ \\
\hline Thermocyclops decipiens & $60(987)$ & $53(620)$ & $57(571)$ & $56(391)$ & $60(612)$ & $56(340)$ & $54(480)$ & $60(331)$ \\
\hline Thermocyclops minutus & $41(337)$ & $37(237)$ & $32(155)$ & $41(111)$ & $31(217)$ & $32(139)$ & $37(99)$ & $29(24)$ \\
\hline Total richness & 82 & 76 & 76 & 80 & 86 & 85 & 81 & 88 \\
\hline
\end{tabular}




\section{Table 3 (on next page)}

Results ( $P$-values) of the four-way richness and abundance ANOVA for the zooplankton groups.

Notes: Year indicates the sampling years (2003-18); period refers to winter and summer; reservoir refers to Salto Santiago and Salto Osório reservoirs; and environment refers to the four environments (fluvial, transitional, lacustrine, and downstream). Significant differences $(P<0.05)$ are shown in bold; asterisks indicate an interaction between the effects. 
1 Table 3

\begin{tabular}{|c|c|c|c|c|c|c|c|c|}
\hline \multirow[b]{2}{*}{ Effects } & \multicolumn{4}{|c|}{ Richness } & \multicolumn{4}{|c|}{ Abundance } \\
\hline & Total & Rotifera & Cladocera & Copepoda & Total & Rotifera & Cladocera & Copepoda \\
\hline Year & $<0.001$ & $<0.001$ & $<0.001$ & $<0.001$ & $<0.001$ & $<0.001$ & $<0.001$ & $<0.001$ \\
\hline Period & 0.595 & 0.385 & 0.008 & 0.832 & $<0.001$ & $<0.001$ & $<0.001$ & $<0.001$ \\
\hline Reservoir & $<0.001$ & $<0.001$ & 0.033 & 0.586 & $<0.001$ & $<0.001$ & 0.001 & 0.001 \\
\hline Environment & 0.034 & $<0.001$ & 0.471 & 0.195 & $<0.001$ & $<0.001$ & $<0.001$ & $<0.001$ \\
\hline Year*Period & $<0.001$ & $<0.001$ & 0.015 & 0.001 & 0.005 & $<0.001$ & $<0.001$ & $\mathbf{0 . 0 3 3}$ \\
\hline Year*Reservoir & 0.424 & 0.159 & 0.674 & 0.965 & 0.016 & 0.438 & 0.224 & 0.045 \\
\hline Period*Reservoir & 0.979 & 0.723 & 0.024 & 0.56 & 0.188 & 0.421 & 0.039 & 0.687 \\
\hline Year*Environment & 0.847 & 0.986 & 0.751 & 0.146 & 0.436 & 0.437 & 0.604 & 0.81 \\
\hline Period*Environment & 0.264 & 0.916 & 0.064 & 0.74 & 0.047 & 0.097 & 0.128 & 0.039 \\
\hline Reservoir*Environment & 0.042 & 0.174 & 0.158 & 0.584 & 0.041 & 0.484 & 0.402 & $\mathbf{0 . 0 0 3}$ \\
\hline Year*Period*Reservoir & 0.192 & 0.186 & 0.463 & 0.557 & 0.946 & 0.654 & 0.853 & 0.5 \\
\hline Year*Period*Environment & 0.981 & 0.944 & 0.999 & 0.901 & 0.988 & 0.99 & 0.997 & 0.981 \\
\hline Year*Reservoir*Environment & 0.987 & 0.467 & 0.986 & 0.887 & 0.899 & 0.925 & 0.962 & 0.883 \\
\hline Period*Reservoir*Environment & 0.987 & 0.524 & 0.653 & 0.461 & 0.928 & 0.207 & 0.942 & 0.75 \\
\hline Year*Period*Reservoir*Environment & 0.996 & 0.988 & 0.996 & 0.447 & 0.952 & 0.996 & 0.989 & 0.966 \\
\hline
\end{tabular}

2 


\section{Table 4 (on next page)}

Similarity of percentages analysis (SIMPER) indicating zooplankton species contributions to composition among years, periods, and environments in the Salto Santiago and Salto Osório reservoirs.

Notes: Only taxa that contributed the most to dissimilarity (average dissimilarity values/SD

$>1$ ) are presented. Values represent the percentage contribution of each species to group dissimilarity; na, no analysis. 


\section{Table 4}

\begin{tabular}{|c|c|c|c|c|c|c|}
\hline \multirow[b]{2}{*}{ Taxa } & \multicolumn{3}{|c|}{ Salto Santiago } & \multicolumn{3}{|c|}{ Salto Osório } \\
\hline & Year & Period & Environment & Year & Period & Environment \\
\hline \multicolumn{7}{|l|}{ Rotifera } \\
\hline Asplanchna sieboldii & 8.0 & 7.5 & na & 2.2 & 2.2 & 2.3 \\
\hline Brachionus calyciflorus & - & - & na & 1.5 & 1.5 & 1.5 \\
\hline Conochilus sp. & 10.4 & 10.4 & na & 5.1 & 5.3 & 5.2 \\
\hline Euchlanis dilatata & 2.2 & 2.3 & na & 2.6 & 2.7 & 2.6 \\
\hline Hexarthra sp. & 3.7 & 4.3 & na & 2.8 & 3.0 & 2.9 \\
\hline Kellicottia bostoniensis & 3.1 & 2.9 & na & 3.3 & 3.1 & 3.2 \\
\hline Polyarthra sp. & 11.0 & 10.1 & na & 7.2 & 6.9 & 7.3 \\
\hline Synchaeta sp. & 3.3 & 3.0 & na & 2.6 & 2.5 & 2.6 \\
\hline Trichocerca cylindrica & 1.6 & 1.6 & na & 2.1 & 2.2 & 2.1 \\
\hline \multicolumn{7}{|l|}{ Cladocera } \\
\hline Bosmina hagmanni & 9.1 & 8.9 & na & 9.2 & 9.0 & 9.1 \\
\hline Ceriodaphnia cornuta & 10.6 & 11.3 & na & 13.1 & 13.5 & 13.1 \\
\hline Ceriodaphnia silvestrii & 5.4 & 5.4 & na & 8.7 & 8.7 & 8.7 \\
\hline Daphnia gessneri & 3.7 & 3.6 & na & 7.8 & 7.8 & 7.7 \\
\hline Diaphanosoma spinulosum & 3.2 & 3.6 & na & 4.1 & 4.5 & 4.2 \\
\hline Moina minuta & 4.6 & 4.9 & na & 6.9 & 7.0 & 6.8 \\
\hline \multicolumn{7}{|l|}{ Copepoda } \\
\hline Notodiaptomus henseni & 3.4 & 3.5 & na & 5.0 & 4.8 & 5.1 \\
\hline Notodiaptomus transitans & 4.8 & 5.0 & na & 4.5 & 4.3 & 4.4 \\
\hline Thermocyclops decipiens & 1.7 & 1.6 & na & 2.2 & 2.1 & 2.2 \\
\hline Average dissimilarity (\%) & 72.7 & 74.7 & na & 72.5 & 72.4 & 71.8 \\
\hline
\end{tabular}

